\title{
La sonrisa del Caudillo
}

\author{
Seguido de "La sonrisa del Caudillo. Vallejo-Nájera y el robo \\ de niños. De la realidad a la ficción"
}

\author{
Rubén Buren \\ rubenburen@yahoo.es
}

Rubén Buren (Madrid, 1974) es dramaturgo, director y profesor de Interpretación (UCM). Profesor de Guion de ficción, Estructuras Dramáticas y Storyboarding en el Grado de Diseño y desarrollo de Videojuegos y en el Grado de Cine de Animación en la Escuela Universitaria de Diseño, Innovación y tecnología ESNE (U. Camilo José Cela y U. Juan Carlos I). Actualmente está preparando su tesis doctoral sobre Melchor Rodríguez, "El ángel rojo". Formado en la Escuela Libre de Interpretación de José Sanchis Sinisterra, ha ganado varios premios de teatro (Mención Especial, Premio Lope de Vega de teatro 2010) y algunos de sus textos han sido estrenados en España, Grecia o Sudamérica. Ha trabajado como guionista de televisión y tiene publicados varios libros de teatro y novela.

Entre sus obras, mayoritariamente de trasfondo histórico y político, cabe destacar: Maquis, sobre los problemas de la guerrilla antifranquista en 1949; La entrega de Madrid, un texto que redescubre al anarquista Melchor Rodríguez "El ángel rojo"; La sonrisa del Caudillo, sobre Vallejo-Nágera y los niños robados en las cárceles; España 82, sobre la crisis económica y social de la España de entonces; Próxima Estación sobre la difícil incorporación a la universidad de la mujer; 186 Escalones, un drama sobre los españoles en el campo de concentración de Mauthausen. Actualmente está preparando, entre otros proyectos de cine y novela, una trilogía sobre Durruti, García Oliver y Federica Montseny; también una revisión sobre los últimos días de Lorca en la Cárcel provincial de Granada. Por último, un libro sobre el desarrollo del Guion en los Videojuegos, asignatura que dirige e imparte en la universidad. Como músico y cantautor tiene varios discos publicados con diferentes compañías y formaciones; y como pintor y dibujante ha realizado una docena de exposiciones, tiene varios premios y ha dibujado múltiples series de dibujos animados para televisión. 
Rubén Buren

\section{PERSONAJES}

ALEJANDROJARDIEL

ANTONIO VALLEjo NÁGERA

CARMEN

DON ADOLFO

MARÍA TOPETE

REMEDIOS

MARTÍN 
La sonrisa del Caudillo

«En contestación a su escrito del 10 del actual proponiendo la creación de un Gabinete de Investigaciones Psicológicas cuya finalidad primordial será investigar las raíces psicofísicas del marxismo, manifiesto que de conformidad con su mencionada propuesta, autorizo la creación del mismo».

Francisco Franco. Telegrama $n^{\circ} 1565,23$ de agosto 1938. Entregado en la Inspección de Campos. 
Rubén Buren

Prisión de Madres Lactantes de San Isidro, Madrid. 1941.

KAMCHATKA N03 - MAYO 2014 


\section{Escena I}

(Despacho de MARÍA TOPETE. ADOLFO habla por teléfono, impaciente; quiere colgar. Fuma nervioso. Siempre que habla con su mujer tiene prisa, una prisa seca, mezcla de apatía y desesperación.)

ADOLFo: Pero te quieres calmar de una vez... ique me estás poniendo nervioso!.... Bueno, tengamos la fiesta en paz... que ya lo hemos hablado... Con tanto trajín como has tenido no me extraña... ¿ Te tomaste la pastilla para dormir?... (Suspira.) Sabes que es lo mejor... no podemos seguir así, que eso no es natural, que la gente... ya... ya... hemos hecho todo lo que está estaba en nuestra mano y nada... Sí, ya lo he pensado muchas veces... ésta es la única solución... además, que lo hace mucha gente, que sí... Ni te imaginas a quiénes he visto pululando por aquí... Que sí, no empecemos cariño... Es una labor social que debemos hacer entre todos... míralo así, estamos haciendo una buena acción... Margarita, mi amor... no empecemos... sí, ya lo hemos hablado, a lo mejor dentro de unos años te florece uno natural... Sí... Debemos enfrentarnos a los problemas que nos da la vida, ¡que no es para tanto, coño!... No empieces también con eso, si viajo es porque tengo que viajar no porque no quiera estar contigo... que no huyo de ti, no digas tonterías, ya lo hemos hablado muchas veces, si no te quedas pues no te quedas... Tú que eres tan beata, a lo mejor es una misión sagrada que nos da... no, no es eso... ¡Joder!... ya sé que no estás segura, nunca estás segura de nada... pero hay que hacer lo que hay que hacer...

(Entra MARÍA TOPETE. ADOLFo le saluda besándole la mano como si fuera una monja. A ella le hubiera encantado ser monja, pero nunca se atrevió a coger los hábitos.)

ADOLFO: Bueno, mi amor, Margarita, que ha venido la Directora... sí, no te preocupes. Adiós, adiós... sí, yo también a ti... ¡Adiós! (Cuelga.)

TOPETE: Don Adolfo, qué grata su visita, me alegra conocerle en persona. Siempre es un honor ver por aquí a un Camisa Vieja como usted. Nos honra en nuestro humilde hogar... ¿Ha podido hablar con su mujer?

ADOLFO: Sí-sí, gracias Doña María por dejarme hacer la llamada... ya sabe, está un poco trastornada con todo esto, usted se hará cargo.

TOPETE: Es normal, estas cosas remueven lo más femenino, la maternidad no es cosa baladí. Pobres, pobres... debe usted entenderla, haber dado a luz a dos criaturas muertas al nacer... Eso es una carga que pesa en el alma... Pero no hablemos de 
penas, que aquí estamos para hacer el bien a esta nuestra Nueva España. Cada uno con su labor.

ADOLFO: Dice bien, Doña María, dice bien...

TOPETE: Bueno vayamos a lo nuestro... (Abre un libro y repasa ciertas notas.) El problema que tenemos en estos meses es el de los niños... todo el mundo quiere varones y ya no nos quedan recién nacidos... por desgracia en estos días ha muerto el crío del que hablamos, de tiña. Una pena, parecía sano y bien guapo que era, pero nació débil el pobre. Ya se sabe que estos lugares no son buenos para las criaturas... el frío, los escasos medios de los que disponemos... Además, las "gestiones" no son fáciles, hay que hacer todo con mucha mano izquierda y buena fe. Algunos familiares están muy encima y no podemos dar en adopción a cualquiera. Es una pena.

ADOLFO: (Algo enfadado.) Pues es una contrariedad...

TOPETE: Por otro lado, las niñas en esta situación pueden tomar los hábitos y así redimen el mal hecho por sus padres... a lo mejor, a su mujer, Doña Margarita, con lo buena cristiana que es, le gustaría preparar una criatura para Dios.

Adolfo: No sé... Pues sí, es una contrariedad, porque yo... bueno, ya me entiende, no es que tenga nada en contra de las mujeres pero yo quiero... mi apellido, ya sabe...Un hombre es un hombre.

TOPETE: Ahí tiene usted razón. Que siempre hace falta un varón que ilumine la casa. Pero el Señor siempre aporta luz cuando todo parece perdido, piense usted en Jesucristo (Mira el libro.) Tenemos a una pobre, una madre que está a punto de dar a luz. Ella es sana y tiene buen lustre... ¡y mucho carácter! Seguro que nace una hermosa criatura. Es de las hembras más fuertes que tenemos... La pobre está condenada para reunirse con el Señor y redimir sus pecados pero, ya sabe usted, que no se puede aplicar la pena hasta que no alumbre. Es un poco díscola y la hemos tenido que sacar de la cárcel de Ventas (Revisa los libros.) Don Adolfo... ¿ iy mayores? ¿No le importaría hacerse cargo de una criatura de dos o tres añitos?

\section{(Entra JARDIEL.)}

JARDIEL: Perdón, Doña María, pensaba que estaba usted sola...

TOPETE: No, no es molestia. Bienvenido a nuestro hogar. Don Adolfo, le presento a nuestro nuevo psiquiatra, Alejandro Jardiel, nada menos que recomendado por Don Antonio Vallejo-Nágera.

JARDIEL: ¿Pero es...?

TOPETE: Sí, el mismo, nuestro héroe del Alcázar. 
JARDIEL: Vaya, es un honor... he visto la película y me quedé sin palabras. Lo que pasaron ustedes allí nos sirvió de ejemplo a todos. Es un honor conocerle, me quedo sin palabras...

ADOLFO: Bueno, el honor es mío, conocí a su padre cuando era cadete. Es un honor estrechar la mano de su hijo.

JARDIEL: Repito: el honor es mío. En fin, no molesto más, Doña María, siento la interrupción y...

TOPETE: Vaya, vaya y hable con Cipriano, él le acompañará a su habitación.

(JARDIEL sale.)

ADOLFO: Retomando, Doña María, es por mi mujer, que no quiere uno de esos niños que ya están hechos, que tiene miedo a que la mire como si fuese una extraña... además ya sabe cómo es la sociedad de provincias, que la gente habla. Yo no quiero que la gente chismorree por ahí, no, no... que ya hemos tenido bastante estos años. La gente inventa unas cosas... Preferimos un recién nacido.

TOPETE: Pues no se hable más, Don Adolfo. Si quiere puede ir usted al Auxilio Social o al Patronato de Menores, quizá allí encuentre lo que anda buscando.

ADOLFo: Bueno, Doña María, quizá tengamos suerte... yo estas cosas, prefiero hacerlas en confianza, ya me entiende. Que remover muchos papeles luego trae malos entendidos y...

TOPETE: En este... hogar, cuidamos mucho del futuro de nuestra España y rezamos por la correcta dirección de nuestra raza. En ningunas manos va encontrarse mejor una criatura que en las suyas, Don Adolfo.

ADOLFO: No hay nada como un ambiente decente y religioso desde el principio, eso es verdad.

TOPETE: Ahí tiene usted toda la razón, Don Adolfo, es mejor criarles antes de que tengan conciencia de las cosas para que no hayan podido desarrollar ese... problema. Y nadie mejor que su esposa, Doña Margarita.

ADOLFO: ¿Porque lo que está claro es que el problema no se hereda?

TOPETE: (Ríe levemente.) Claro que no, ¿ ¿no ha leído al profesor? El marxismo es puramente ambiental, es imposible que se desarrolle si se crían desde el principio en un ambiente adecuado.

ADOLFO: Sí, sí... pero no deja de preocuparme. Imagínese yo, con mis circunstancias. Mi posición.

TOPETE: Pierda cuidado, Don Adolfo, que una cosa es segura. Si yo tuviera alguna duda al respecto no admitiría estas adopciones. Eso se lo garantizo.

ADOLFO: ${ }_{\mathrm{C}}$ Y la madre? ¿Cómo es?... ya me entiende... ¿ ¿Es guapa? 
TopeTE: Muy guapa, Don Adolfo, sana, con buena dentadura, educada... parece mentira que hiciera lo que hiciera.

ADOLFO: ¿Podríamos verla?

TOPETE: Claro, Don Adolfo, pierda cuidado, todo eso déjelo de mi cuenta... ¿ $\mathrm{S}$ Se encuentra usted bien?

ADOLFO: Sí, sí... el viaje... ¿ Le importa? (Saca un cigarrillo.)

TOPETE: Como no, Don Adolfo, como no.

\section{(ADOLFO fuma.)}

TOPETE: Tiene usted que cuidarse (Sonríe.) Ahora que va a ser padre tiene una gran responsabilidad. Ya verá, ya... eso es lo más grande. La labor más divina que nos ha encomendado el Señor.

ADOLFO: Ya sabe... estas lesiones de guerra, con la humedad...

TOPETE: Un héroe es lo que es usted, Don Adolfo, un héroe.

ADOLFO: Todo este asunto, Doña María, quedará entre nosotros... Vamos, que la partida de nacimiento y demás...

TOPETE: No se preocupe Don Adolfo, nos ampara la ley. Hay mucha gente que se preocupa por el bien de estas pequeñas almas. A la criatura, que esperemos que sea niño, se lo llevan ustedes directamente registrado desde aquí, con la partida de nacimiento y todos los papeles en regla... Eso de bueno tiene tratar con recién nacidos, que agiliza mucho los trámites... Por supuesto que nosotras, las pobres funcionarias que velamos por el correcto funcionamiento de esta institución penitenciaria, le agradecemos cualquier aportación que usted pudiera darnos, ya sabe... somos una congregación pequeña... con muchos gastos.

ADOLFO: No se preocupe por eso, Doña María, ya me habían comentado...

(ADOLFO saca la chequera del bolsillo y escribe una cantidad. Arranca un cheque y se lo entrega a DOÑA MARÍA.)

ADOLFO: ${ }_{\mathrm{C}}^{\mathrm{LL}}$ parece...?

TOPETE: (Leyendo la cantidad.) Más que suficiente, Don Adolfo, tiene usted ganado el cielo...

ADOLFO: Y dice usted que esa mujer... la madre... ¿ ¿es sana?

TOPETE: Sanísima, casi parece increíble. Ni una fiebre ha cogido desde que vino.

ADOLFO: ${ }_{\mathrm{C}} \mathrm{Ha}$ hecho mucho mal en la guerra?

TOPETE: Mucho... las anarquistas son como alimañas... pero son cosas del pasado, Don

Adolfo, ahora hay que olvidar y perdonar. Esas pobres mujeres se han visto 
arrastradas, ya sabe usted... las pobres no tienen la culpa de haber sido desviadas del camino de la fe. Gracias a Dios, nuestra Cruzada ha vuelto a poner las cosas en su sitio. (Guardando el cheque dentro del libro.) Dios proveerá, Don Adolfo...

(DON ADOLFO mira por la ventana, de pie. Seguro de sus decisiones. TOPETE ordena la mesa de su despacho y le observa, guardando a buen recaudo el cheque que le acaba de dar. TOPETE, se acerca a Don Adolfo y observa también por la ventana.)

ADOLFO: Tienen ustedes unas instalaciones muy cuidadas...

TOPETE: Hacemos lo que podemos, Don Adolfo, hacemos lo que podemos... Cipriano, que cuida de todo... 


\section{Escena II}

(REMEDIOS y CARMEN en una celda. No es la celda de siempre, parece como más nueva. Las paredes están pintadas y no tiene demasiada humedad. REMEDIOS se huele los sobacos, como buscando un olor que ha perdido.)

REMEDIOS: ;Suelta ese trapo ya que te vas a volver loca!

CARMEN:;Déjame!, ¡es mi hïjo!

REMEDIOS: Carmen, que tu hijo está muerto...

CARMEN: No está muerto... (Canta una nana, mientras da de mamar al trapo que tiene arropado en las manos. Todavía tiene leche en el pecho porque se la saca apretándose todas las noches, para que no se corte. Los pezones le huelen a podrido, los tiene en carne viva, por eso, de vez en cuando, se echa saliva para mitigar el escozor.)

Si por un momento

la luz yo tuviera

esta noche negra

Con una navaja

cortaría tus cadenas

para verte volar

Si yo fuera la dueña

de tus pensamientos

de tu soledad

yo daría mi vida

por tu libertad

¡Ay, lluvia de primavera

lluvia de mi corazón

que me corre por las venas

de tinieblas y tormenta!

¡Ay, lluvia de primavera

lluvia de mi corazón!

REMEDIOS: Lo que daría por llegar al ventanuco... huele a fresco. Seguro que ya es primavera... esta brisa... i ${ }^{\text {te }}$ imaginas pasear por el campo, por el pueblo? 
CARMEN: Yo paseo con mi niño, por la calle Mayor, vestida de domingo. Los domingos dan merengue, y yo le compro merengue a mi niño. Merengue blanco. ¿Quién está tosiendo? Deja de toser mi niño, deja de toser.

REMEDIOS: Vas a perder la cabeza como sigas así, Carmen, llevas demasiados días delirando y este no es un buen sitio para perder la cabeza. Tienes que ser fuerte.

CARMEN: Va a ser niña.

REMEDIOS: ¿ ${ }_{\mathrm{C}}$ Tú crees? Sí... por la lata que da no sé... va a ser revoltosa, eso seguro. Dicen que están llegando indultos para algunas, que a Matilde la han dejado salir con su hijo... y Libertad y Merche, que todas han salido... ¿ ¿Nos dejarán ir al patio?

CARMEN: Yo no quiero ir al patio.

REMEDIOS: Aquí hay demasiada humedad... y hace casi una semana que no salimos. El puñetero Manzanares que cala los huesos.

CARMEN: Por lo menos no estamos hacinadas como las otras, así mi niño puede respirar, que antes no respiraba, en Ventas no se podía respirar... (Al trapo.) Ya no toses... $\dot{\mathrm{c}}^{\text {A que no? }}$

REMEDIOS: ¿Y por qué nos separan a nosotras?

CARMEN: Será por el cariño que te tiene tu jardinero, el Cipriano.

REMEDIOS: Pues gracias a él comemos caliente.

CARMEN: ¿A cambio de qué?

REMEDIOS: Ya sabes a cambio de qué... prefiero hacerlo por las buenas a que me peguen como antes. Así solo es uno, por lo menos solo es uno, no como antes... y me trata bien.

CARMEN: Eres una puta.

REMEDIOS: Sí, lo soy. Pero estoy viva, no como las otras, y tú también, que también consigo medicinas para ti... ¿ $\mathrm{c}$ no las quieres?... Y te aseguro que mi hija no se va a morir como las demás. Es una niña (Se toca.) Lo sé, esas cosas se saben, las madres lo sabemos.

CARmen: Todos los niños mueren... menos el mío, el mío es tan fuerte... (Canta.) Lluvia de primavera, lluvia de mi corazón... Como un caballo del monte.

REMEDIOS: No sé cómo tienes ganas de cantar, a mí me duele todo el cuerpo. Días le doy yo a esto...

(Entra TOPETE. Ellas se colocan en pie.)

TOPETE: Carmen, trae eso (Se acerca y le quita el trapo. CARMEN se queda inmóvil mirando al suelo, callada.) ¡Qué asco, está podrido!... Y no abras la boca si no quieres que te lleve al cuarto de la manguera.

REMEDIOS: ¿Por qué no podemos ir al patio? 
TOPETE: Viene un señor muy importante a veros, así que vamos a estar calladitas, a responder a lo que nos pregunten y a no tener problemas, ¿estamos?

REMEDIOS: Estamos, por eso nos han aseado, para que no olamos a mierda que es como olemos siempre...

TOPETE: ¿Quieres manguera?

REMEDIOS: No, señora Directora.

TOPETE: ¿ YY tú, Carmen?

(CARMEN no levanta la mirada del suelo y canturrea la nana.)

REMEDIOS: Está así desde...

TOPETE: Pobrecita, que el señor lo tenga en su gloria, ¡pobre criatura! (Se hace la señal de la cruz.)

\section{(TOPETE sale y entra con ADOLFO.)}

TOPETE: Aquí las tiene, Don Adolfo.

REMEDIOS: ¿Es usted médico?

ADOLFO: No, señora... digamos que...

REMEDIOS: No será otro de los del cine, que nos graban bebiendo vasos de leche y magdalenas. Pues que sepa que aquí ni leche ni magdalenas: cucarachas y serrín, eso es lo que nos dan. Que luego nuestras familias piensan que vivimos en un chalé.

Adolfo: No señorita. Soy diplomático y estoy haciendo un reconocimiento de las instalaciones.

REMEDIOS: Pues a ver si la señora Directora le lleva a ver a mis compañeras, que hay más de 40 en un lugar más pequeño que este, entre mierda, pis y ratas. Y que nos dejen ver a nuestros niños, que casi ni leche nos dejan darles... como estamos secas. Solo una hora para mamar y a llorar todo el día, eso no es cristiano, ¿ ¿no?...

TOPETE: No le haga caso, ya sabe cómo son estas pobrecitas... mienten más que hablan.

ADOLFO: Ya he tomado nota de todo, señorita, no se preocupe... Veo que está usted en estado, ¿para cuándo lo espera?

REMEDIOS: Y a usted qué le importa, ¿qué es usted, matrona?

TOPETE: Remedios, no empecemos que te llevo al "cuarto".

REMEDIOS: Pues lléveme, llévenos a las dos... que la Carmen ha perdido la chaveta con lo del crío... que se le ha muerto, sabe usted, "Don Diplomático", se ha muerto de hambre y de neumonía, como todos aquí... 
ADOLFO: Es usted muy rebelde, eso es bueno, pero en su estado debería estar más calmada, ¿no le parece?

REMEDIOS: Si me trae un indulto yo me calmo.

ADOLFO: Puede ser, todo puede ser... pero su actitud... (A CARMEN.) $\mathrm{C}$ Se encuentra usted bien?

REMEDIOS: ¿Esta?, sí... muy bien, no hay más que verla. Le han matado al niño nada más nacer.

ADOLFO: ¿De dónde es usted?

CARMEN: De Sevilla, de Lebrija.

ADOLFO: ¡Ah!, un bonito lugar... yo tuve la suerte de pasar allí, por Sevilla, alguna semana santa y fue emocionante. Sí, muy emocionante...

(CARMEN le enseña los pechos abriéndose la camisa. Se los aprieta para juntarlos todo lo que puede. ADOLFO se asusta un poco. TOPETE le da una bofetada y CARMEN cae al suelo.)

TOPETE: Ya le dije que tuviera cuidado, son como alimañas.

REMEDIOS: Doña María, y el patio ¿qué?

ADOLFO: ¿Y el padre?

REMEDIOS: El padre (Ríe.) Si llevo presa dos años pues eche usted cuentas... (A CARMEN.) ¡Qué te parece! ¡Que quién es el padre dice! ¡Nos ha merengao!... pregunte en Gobernación, allí seguro que lo saben.

ADOLFo: Bueno, Madre, vamos a hacer una cosa... (Saca la chequera y rellena un cheque que le da a TOPETE.) A partir de ahora a esta... señora, que no la falte de nada, comida de primera, paseos, ropa seca y una cama en condiciones, mantas y esas cosas. Y paseos por el patio (A REMEDIOS.) que tiene usted que ver la Casa de campo.

REMEDIOS: Ve usted, ¡así se habla!... ves Carmen, ves como Dios existe, que es este señor...

TOPETE: No blasfemes...

REMEDIOS: Bueno Don Diplomático, yo le acepto los favores, pero resulta que o es para las dos o nada, que Carmen y yo somos como uña y carne.

(TOPETE hace el ademán de levantar la mano para abofetearla.)

ADOLFO: Déjela Madre, déjela... ya verá como un baño caliente le apacigua el carácter... ¿Hay algún problema?

TOPETE: Ninguno Don Adolfo, todo se dispondrá como usted quiera. En esta habitación la pared siempre está templada por la lumbre, como está junto al hogar... aquí estarán bien. 
(TOPETE se dirige hacia la puerta y ADOLFO con ella.)

CARMEN: Señora Directora... ¿ ¿me puede dar el trapo?

TOPETE: Toma anda (Se lo tira.)Y a ver si lo lavas que huele a podrido. Dios te dé luz, hija, Ave María Purísima...

(Salen ADOLFO y TOPETE.)

REMEDIOS: ¿Ves, Carmen? Ahora voy a tener a mi bebé y después llegará el indulto.

CARMEN: Nunca hay indulto, ya lo sabes, nunca hay indulto.

(REMEDIOS coge el trapo, se lo prepara a CARMEN como le gusta y se lo da.)

REMEDIOS: Toma, anda, que seguro que tiene hambre.

CARMEN: Eres una puta, eres una puta...

REMEDIOS: Ya verás, Carmencita, que si damos unos paseos vas a ponerte bien, otra vez, que el sol aclara las ideas... y aquí parece que siempre es de noche.

CARMEN: Nadie da nada gratis.

REMEDIOS: ¿Y qué puede querer este señor, si es un mandamás?

CARMEN: (Canta.) Lluvia de primavera... 


\section{Escena III}

(ANTONIO está leyendo unos informes. Entra JARDIEL.)

JARDIEL: Perdón, Don Antonio (Saluda militarmente.)

ANTONIO: Pase, pase... (Le saluda afectuosamente.) Descanse Jardiel, vaya... está usted hecho un hombre. No me lo podía creer cuando vi las fotos, se parece usted tanto a su madre... Ese lustre. ¡Vaya mujer!

JARDIEL: Eso dicen.

ANTONIO: Yo hubiera perdido la cabeza por ella si no llega su padre a quitármela antes.

JARDIEL: Mi padre siempre habla de ustedes, de cuando jóvenes.

ANTONIO: Buenos tiempos aquellos, me acuerdo de cuando su padre y yo andábamos de cuartel en cuartel, en África, y usted correteaba de un lado para otro con su hermano, de aquí para allá.

JARDIEL: Ha pasado el tiempo, Don Antonio.

ANTONIO: Ya, para algunos más que para otros. Por cierto, me enteré de lo de Íñigo, tarde, me enteré ya sin tiempo para... Fue una pena. Algunos han tenido que dar su vida por esta Cruzada nuestra.

JARDIEL: Gracias Don Antonio, en la familia recibimos su telegrama y la corona de flores, mi madre se lo agradeció mucho. Mi padre está... bueno, no lo supera.

ANTONIO: Un hijo es un hïjo.

JARDIEL: (Saca una botella.) Mire... mi padre le envía un pequeño presente. Dice que usted se acordará.

ANTONIO: ¡Hombre!... ¡Buen vino, sí señor! (Ríe.) Su padre siempre tuvo un gusto excelente. Buena tierra la suya para la garnacha...

JARDIEL: He traído tres cajas, y un par de jamones, lo he dejado abajo, para que se lo lleven donde usted ordene.

ANTONIO: No tenían ustedes que haberse molestado... Su padre no cambiará...

JARDIEL: No es molestia. Además ya sabe cómo somos en mi tierra...

ANTONIO: En su tierra ya se sabe (Ríe.) Muy perseverantes, sí, muy perseverantes. Bueno, bueno, la verdad es que por aquí va haciendo falta sangre nueva. Nada menos que teniente, ¡cuando me lo dijo su padre no podía creerlo! ¡Aquel chiquillo!... Viene haciendo falta que los jóvenes nos releven del cargo de estas investigaciones y 
necesitamos gente de raza, como usted, Jardiel, gente con espíritu y fuerza. Con buena cuna.

JARDIEL: Gracias, Don Antonio, debo decirle que al principio no me gustó que mi padre se pusiera en contacto con usted pero luego me ilusioné cuando leí su carta. Debo felicitarle, Don Antonio, he leído algunos de sus artículos y me han parecido, cuando menos, cómo decirlo: edificantes.

ANTONIO: No son más que investigaciones, hemos tenido suerte de encontrarnos estos años con tanto sujeto patológico. Ya se dará usted cuenta del caldo de cultivo con el que contamos en estos lugares. Lamentablemente, no hemos conseguido, todavía, revertir su tendencia. Pero hemos llegado a muy buenas conclusiones.

JARDIEL: Para mí son como libros de cabecera... Usted me dirá.

ANTONIO: Sí... ya sabe, lo que comenzó siendo un modesto trabajo en Burgos, en San Pedro de Cardeña, con los brigadistas, se ha convertido en un estudio extenso en la cárcel de Málaga. Aquí y en Ventas va a tratar usted con elementos muy diferentes: las madres. Ya sabe que estos centros carcelarios tienen como intención última lograr la regeneración física y moral de los sujetos femeninos delincuentes, y así poder devolverlas a nuestra sociedad sanas de cuerpo y espíritu. Estos sujetos no están preparados para dar a sus vástagos un buen "ambiente", por eso creemos que en la selección de algunos, de los mejores, para llevarles al cuidado de familias falangistas y leales.

JARDIEL: Como dice mi padre, hay que tener cuidado, que ahora todo el mundo es falangista (Ríe.)

ANTONIO: (Ríe.) Su padre... tan ácido como siempre... Sí me gustaría que se familiarizara con la metodología que utilizamos... el psicobiograma de Kretschmer, el diagnóstico de reacción temperamental primaria de Neymann-Kohlstedt; algo de Marston; y el método de coeficiente intelectual de Yerkes (Le va dando papeles.) ¿Los conoce?

JARDIEL: (Mira los papeles.) Sí, Kretschmer, Yerkes... (Repasa algún informe.) Sí, lo que me comentó en sus cartas. He estudiado todos a fondo.

ANTONIO: Como ya le he dicho, el trabajo que llevamos a cabo con el teniente Martínez en la prisión de Málaga no fue más que el comienzo. Aquí, en el centro de mujeres lactantes, va a disponer de un número limitado de sujetos. No queremos hacer ruido... Pero muy interesantes, ya lo verá. Yo, como usted comprenderá, tengo que ocuparme de mi cátedra en la universidad, aunque estaré a su disposición para lo que precise. La finalidad última de nuestro cometido es regenerar a estas pobres almas descarriadas.

JARDIEL: Estoy a sus órdenes para lo que usted estime conveniente. Estoy deseando ponerme manos a la obra. 
ANTONIO: Jardiel-Jardiel, relájese, guarde ese ímpetu para el trabajo. Por eso le llamé, no crea usted que lo hice por la amistad que me une con su familia. Leí sus estudios de campo en el frente del Ebro, me parecieron brillantes... no piense que no me han llegado sus conclusiones sobre la neurosis de guerra de algunos soldados. Muy interesantes, sí señor... ¿ Ha conocido ya a Herr Mayer?

JARDIEL: Me ha sorprendido... no sabía que hubiera alemanes por aquí.

ANTONIO: En Alemania están avanzando enormemente en la investigación del Gen Rojo. Herr Mayer ha colaborado estrechamente con el mismísimo Himmler en el Instituto para la Investigación y Estudio de la Herencia de Mecklenburg. Le sorprenderían sus conclusiones sobre higiene racial. Una referencia para esta nueva era. Yo, particularmente, no creo en eso del Gen, más bien creo en el factor ambiental... pero de eso se trata, de averiguarlo. Si podemos demostrar nuestras investigaciones supondría un buen avance hacia la depuración racial.

JARDIEL: La verdad es que estoy impresionado, Don Antonio, abrumado de que se haya acordado de mí para este trabajo. No sé si estaré a la altura. Bueno, no le molesto más que veo que está usted ocupado... le aseguro que voy a poner lo que esté en mi mano... espero no defraudarle.

ANTONIO: No lo hará, Jardiel, no lo hará, usted es como su padre: un militar de pura cepa. Eso se lleva en la sangre... Tengo que avisarle de que los sujetos Marxistas Delincuentes Femeninos con los que va a realizar sus investigaciones, no son un campo tan sencillo como el de los soldados; debe estar siempre en guardia. Si la mujer es habitualmente de carácter apacible, dulce y bondadoso se debe a los frenos sociales, pero, como usted ya sabe, el psiquismo femenino tiene muchos puntos de contacto con el infantil y el animal.

JARDIEL: Como le dije, sus artículos son como libros de cabecera para mí, ¿ime permite? (Saca un cuaderno de notas, busca una hoja y lee.) "Cuando desaparecen los frenos que contienen socialmente a la mujer y se liberan las inhibiciones frenatrices de las impulsiones instintivas, entonces despiértase en el sexo femenino el instinto de crueldad y rebasa todas las posibilidades imaginadas, por faltarle las inhibiciones inteligentes y..."

ANTONIO: Pare-pare, me halaga usted, por eso precisamente lo he seleccionado. Veo que no me he equivocado. Perseverante y prolijo, como su padre... Bueno, duerma, coma algo, estudie estos informes y mañana se pondrá manos a la obra.

JARDIEL: Muchas gracias, Don Antonio. Es un orgullo para mí y para mi familia.

ANTONIO: El orgullo es mío, y nada de "don", que ahora somos colegas. Bienvenido al Gabinete.

JARDIEL: Es un honor. 
(Se dan la mano y sale. Antonio sigue repasando documentos. Coge el teléfono y marca.)

ANTonio: Con Doña Pilar por favor, de Don Antonio (Espera unos instantes.) Sí, bienbien... no... ningún problema. Está hecho un hombre ya... sí, yo me ocupo. No, no te preocupes, eso déjalo en mis manos, que le voy a tener bien vigilado, como si fuera mi... ¿ ¿Y cómo está?... ¿Sigue igual?... Tiene que superarlo... Íñigo era un buen soldado... a ver si en unas semanas puedo acercarme por ahí... Sí, vamos hablando... ¿A Madrid? ¿ ¿Tú crees que es buena idea?... Vernos, digo, ya no es como... Bueno, si quieres... pero no sé si a él le va a... Bien, un abrazo Pilar, sí, yo... no, gracias a ti.

(Cuelga y se queda pensativo.) 


\section{Escena IV}

(MARTÍN espera en la sala de visitas. Intenta caminar sin que se le note la cojera. Al rato entra REMEDIOS, examina las cosas de la cesta con mucha curiosidad, huele y sonríe.)

MARTÍn: (Mirando hacia la puerta.) Es una suerte que últimamente nos dejen solos un rato, no como a los otros, prefiero estar a solas contigo que con los otros, que casi no nos dejan hablar...

REMEDIOS: Qué querrás tú...

MARTín: Nada mujer, ¿qué voy a querer?... ¿La Topete qué dice de esto?

REMEDIOS: Tú calla, que si se entera me lleva a la manguera... (Rebuscando.) ¿Cada día traes menos en la cesta?

MARTín: Es que como aquí os tratan tan bien, dice tu hermana que habéis salido en el NODO... pues eso, que araña algo, que en casa no sobra, que somos cuatro...

REMEDIOS: Pues dile que no arañe, que eso es mentira... ¿ ¿Sigues sin trabajo?

MARTín: Bueno, algo de allí y algo de allá, pero nada...

REMEDIOS: Eso es lo que os gusta a los hombres, el no hacer ná.

MARTín: Bueno, que no es tan fácil, pero con la pierna y...

REMEDIOS: Ya, pues a ver si te depuran de una vez, que tú por no hacer, ni tenías ni carné del sindicato... mucho vago, eso es lo que hay... pues a ver quién le va dar de comer a ésta cuando venga.

MARTín: Tengamos la fiesta en paz...

REMEDIOS: Es que no veo yo...

MARTÍn: Mujer, es que me sacas de quicio, ¿qué quieres que haga?, nada te parece bastante.

(Pausa.)

MARTÍN: $\mathrm{Y}$, ¿cómo va?

REMEDIOS: ¿El qué?

MARTÍn: Pues el qué va a ser... ¿ el niño? 
REMEDIOS: La niña, que ya te lo he dicho... Va bien, va a ser en estos días.

MARTín: ${ }_{\mathrm{C}} Y$ te ha subido ya la leche?

REMEDIOS: Que no, que siempre estás con lo mismo. Que la leche no sube hasta que no has parido. ¿Qué pasa? ¿Es que no mamaste de pequeño?

MARTín: Bueno, mujer, curiosidad...

REMEDIOS: Ya, curiosidad, que no te conozco yo a ti... tú y tus curiosidades.

MARTín: He estado hablando con mi primo del pueblo, el falangista...

REMEDIOS: Sí, ciy qué?

MARTín: Que me ha dicho que la cosa está como está pero que, a lo mejor, si habla con quien tiene que hablar.

REMEDIOS: ¿El Don Nadie?... Pues dile que se dé prisa, que si no... que este sitio no es bueno para los críos, que se mueren de frío todos los días. Que se pasan las noches tosiendo, que se les oye por entre las rejas, y luego algunos están muertos días hasta que se los llevan.

MARTín: No sé, dicen que las cosas van a mejor, ahora que Hitler va a conquistar todo el mundo... Seguro que se olvidan de lo nuestro, dice mi primo que en unos meses van a necesitar mano de obra para Rusia, como no va a quedar ni un comunista... Que los van a matar a todos.

REMEDIOS: Martín de bueno que eres, eres tonto. Que te crees todas las cosas.

MARTÍN: ¿Por qué lo dices?

REMEDIOS: Yo me sé lo que me digo... Que Rusia es muy grande.

MARTín: Mi primo siempre me ha ayudado.

REMEDIOS: Si no lo digo por tu primo, atontao, que tu primo debe ser como tú, un atontao. Que yo no estoy aquí de perpetua, que tengo la "pepa".

MARTÍn: Tú di que te arrepientes, que te hiciste anarquista porque te engañaron, que ahora has cambiado, afuera la gente está muy mal, está mal la cosa...

REMEDIOS: Ya, aquí no, no te jode...

MARTín: Aquí tenéis para comer, que esto es como un chalé.

REMEDIOS: Martín, que no te creas ná, que nos lavan cuando hay visita y luego a vivir entre mierda. Que mucho dibujito en las paredes pero los niños desaparecen y se mueren. Esto es peor que el infierno.

MARTín: Pero si tú no crees en esas cosas.

REMEDIOS: Pues si creyera, el infierno sería como esto...

(Pausa. MARTÍN mira la puerta, se acerca y escucha.)

REMEDIOS: Martín, ¿ia ti no parece raro lo de mi embarazo? Que tú no me has tocao...

MARTÍ́N: No. 
REMEDIOS: ${ }_{\mathrm{C}}^{\mathrm{Ni}}$ que ahora nos veamos en esta sala, tú y yo solos, y no como las otras?

MARTÍN: No.

REMEDIOS: ${ }_{\mathrm{C}} \mathrm{Y}$ no te parece raro?

MARTín: Pues no, ¿por qué me lo iba a parecer?... en esas cosas no me meto, son cosas tuyas.

REMEDIOS: Ya... mías... No sé... a lo mejor tienes razón... y es mejor así.

(MARTÍN camina de un lado a otro, nervioso.)

REMEDIOS: Estás nervioso, siempre que me tienes que decir algo estás nervioso, ¿qué te pasa?

MARTín: Mira, ¿a que ya no se me nota? Bueno, casi...

REMEDIOS: No, que va, pareces un pato. Si tú eres cojo de toda la vida...

MARTín: De toda la vida no, desde el accidente.

REMEDIOS: Ya, desde al accidente...

MARTín: Bueno, ¿pero tú quieres que hable con mi primo o no?

REMEDIOs: Lo que tú quieras, Martín, ya te lo dicho, lo que tú quieras. ¿Pero tú crees que tengo para elegir?

MARTín: No sé, no sé...

REMEDIOS: Venga que tenemos cinco minutos. Ven anda, acércate... tócalas, que las tengo duras.

MARTÍn: Pero, ¿iaquî?... ¿ ¿y si nos ven?

REMEDIOS: Ven anda, que además tengo los pezones como un botón, como a ti te gustan, que así te llevas un buen recuerdo... ¿ ¿No quieres?, ¿qué pasa? ¿que vienes servido de casa?... ya...

(MARTÍN nervioso, desabrocha la camisa de REMEDIOS y le saca los dos pechos. Comienza a acariciarlos. REMEDIOS le toca los genitales mientras parece que hacen otra cosa. Al cabo, en pocos segundos, MARTín hace un pequeño ruido.)

REMEDIOS: Pero ya... ¡Ay mi Martín!, ¡que cada día tardas menos!

MARTín: Es que estoy nervioso, que puede entrar el guardia y ya sabes cómo se las gastan.

REMEDIOS: Que hoy no va a entrar nadie... abróchate anda.

REMEDIOS: No si ya...

MARTín: ¿ Ya es la hora?

REMEDIOS: Espera que me acicale. No te pongas nervioso.

MARTín: Date prisa, mujer, a ver si va a venir alguien. 
REMEDIOS: ¡Que voy, mírale!... ¡Hace un momento no estabas tan preocupado!... Iba a decir que no tenías prisa, pero prisa-prisa sí que tenías, ceh? (Ríe.) Que no sé ni cómo me hiciste un niño con tantas prisas.

MARTín: Mujer, no digas esas cosas, que a uno le duele...

REMEDIOs: Que lo digo en broma, Martín, que tú eres muy hombre... Oye, ¿ihas conseguido lo que te dije? Es para la Carmen, que va peor cada día.

MARTín: Sí (Saca un trapito con unas pastillas que estaba debajo de la tartera y se lo da.)

REMEDIOS: Martín, tú tienes que hacerte a la idea. Que vas a tener una boca más que alimentar. ¿Qué tal Mari Cruz?

MARTín: Bueno, se ocupa... pero es un poco arisca.

REMEDIOS: Mi hermana siempre ha sido una siesa, pero es buena. Cuando yo falte júntate con ella, que os hará falta compañía... si no lo has hecho ya... i Lo has hecho ya, Martín?

MARTín: No digas esas cosas.

REMEDIOS: Las cosas hay que hablarlas.

MARTín: (Muy nervioso.) Sí, pero con tu hermana... si es que parece que la molesto, que nunca me mira a los ojos.

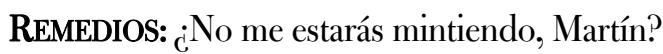

MARTín: ¿Qué dices, mujer?

REMEDIOS: Que mi hermana y tú no habéis...

MARTín: ¡Cómo iba a hacer yo eso!

REMEDIOS: ${ }_{\mathrm{C}} \mathrm{Y}$ por qué estás nervioso cuando saco el tema?... Que siempre que mientes bajas la mirada, como cuando te ibas al bar... y conozco a mi hermana, que no piensa más que en ella... con tal de no estar sola es capaz de abrirse de piernas a cualquiera. Y tú eres bueno y ella lo sabe... Pues falta os haría.

MARTÍn: ¡Eres muy burra, Reme, muy burra!

REMEDIOS: ¿Te la han mirado?

MARTÍN: ¿El qué?

REMEDIOS: ¿El qué va a ser... la cesta?

MARTín: No, las últimas veces no la miran...

REMEDIOS: Como tiene que ser... El Cipriano cumple, por lo menos.

Voz: (Dando unos golpes.) Vamos.

(Pausa.)

REMEDIOS: Dame un beso, anda. Que te quiero, aunque seas un bobo...

(Se besan y REMEDIOS sale. Queda MARTÍN hundido y pensativo.) 


\section{Escena V}

(Despacho. ANTONIO está trabajando. Entra la TOPETE.)

TOPETE: Perdón, Don Antonio. Ha vuelto a venir Don Adolfo, que está intranquilo y ya sabe usted... Quiere hacerle unas preguntas, sobre eso del gen, ya le he dicho que usted es un hombre muy ocupado, que viene solo de visita de vez en cuando y... pero ha insistido, y ya sabe lo generoso que es.

ANTonio: Bueno, Doña María, un hombre de su posición... es normal que esté preocupado con estas cosas. Se juega mucho. Dígale que pase, que encantado le atenderé.

TOPETE: Es usted siempre tan atento, Don Antonio... Tiene usted muchas virtudes, y la más importante es la paciencia.

ANTONIO: (Sonríe.) Eso es mi trabajo, Doña María: paciencia, paciencia y perseverancia.

TOPETE: En estos días, Don Antonio, sí me gustaría que una tarde pudiéramos hablar...

ANTONIO: ¿Está usted preocupada por algo? ¿Le molesta que utilice su despacho? ${ }_{\mathrm{C}}^{\mathrm{La}}$ importuno?

TOPETE: Ni mucho menos, me honra usted viniendo a este humilde hospital. Es... cosas... tonterías... ideas que tiene una y que no sabe explicar...

ANTonio: Pues no se hable más, Doña María, en uno de estos días. Damos un paseo por el jardín y me cuenta sus cuitas.

TOPETE: Siempre usted tan solícito...

(Sale TOPETE. Unos segundos más tarde entra JARDIEL.)

JARDIEL: Buenos días.

ANTONIO: Buenos días, teniente, ¿qué tal sus primeros días?

JARDIEL: Inmejorables, Don Antonio, esta semana ya he empezado a trabajar con algunas reclusas. 
ANTONIO: "Sujetos Femeninos"... distánciese, Jardiel, distánciese que puede perder la perspectiva.

JARDIEL: Tiene usted razón... ¿ ¿Hay pastores por aquí cerca?

ANTONIO: ¿Pastores? ¿ $\mathrm{C}$ Por qué lo pregunta? Creo que hay una finca aquí al lado...

JARDIEL: Es por esos perros, que cuando ladran tiembla la pared.

ADOLFO: Los mastines.

JARDIEL: No sé, no entiendo mucho de perros.

ANTONIO: ¡Pero cómo...! ¿ ¿ las buenas costumbres cinegéticas de su padre?

JARDIEL: Eso lo heredó mi hermano Íñigo... Yo siempre andaba de libro en libro cuando ellos iban a cazar.

ANTONIO: Ahí tiene usted razón, la afinidad... ya sabe, las afinidades de padres a hijos... ¿Sigue teniendo su padre esos perdigueros?

JARDIEL: Sí, siempre intentando mejorar la raza. Ahora ha traído un par de perros de Alemania, dice que son excelentes.

ANTONIO: ¿Sabe una cosa?, estoy pensando en pasar unos días con su familia. Nos hará bien recordar viejos tiempos.

JARDIEL: Nuestra casa es su casa, ya lo sabe. No tiene más que decirlo.

ANTONIO: Es usted muy amable... Acérquese a la finca, ya verá qué hermosos son esos perros... ¿Qué me quería comentar?

JARDIEL: Sí, pare eso quería verle, aprovechando su visita... una de las presas... Carmen, la de Lebrija... ¿La conoce?

ANTONIO: No recuerdo ahora mismo... (Déjeme ver.)

(JARDIEL le enseña una carpeta y ANTONIO echa un vistazo.)

ANTONIO: Sí, un caso típico. Un caso grave de degeneración del biotipo, ¿qué problema tiene con ella?

JARDIEL: No sé, ella no para de decir que su hijo está vivo. Dice que hace casi dos meses que tuvo un hijo, varón, que le escuchó llorar al nacer. He mirado los registros y no hay siquiera partida de nacimiento... no sé, me parece raro todo esto...

ANTONIO:Jardiel, ya le dije... no se meta en cosas de política.

JARDIEL: Pero, no sé... Don Antonio... Echo en falta algo más de control. Quizá esos niños tengan familia y ¿qué derecho...?

ANTONIO: (Sonríe.) Distánciese... ¿Derecho?... Sí, una familia marxista, demócrata, seguro... La Anti-España que ha traicionado a la patria no puede legar apellidos honrados. Deje usted actuar a los que manejan el Nuevo Estado. Ahora nos toca un poco de firmeza para afianzar y evitar nuevos brotes... i Le molestan los perros de noche? Si quiere doy aviso y... 
JARDIEL: No, bueno... como me paso la noche leyendo a veces me distraen. Pero me gusta, me hace sentirme como en casa.

ANTONIO: Y como en casa en ningún lado... Disfrute de Madrid, es una ciudad que ofrece muchas oportunidades a los jóvenes como usted. Mire (Apunta algo en una libreta.) Lo mejor es que vaya a este sitio y pregunte por Zubeldía, dígale usted que va de mi parte. Ya verá cómo se olvida un poco del trabajo...

JARDIEL: Tiene usted toda la razón, Don Antonio, tengo que... pero tengo ya algunos amigos que...

ANTONIO: Y su madre, ¿ cómo está?... ¡Ah, menuda mujer! Su padre tuvo mucha suerte...

JARDIEL: Hace días que no hablo con ella.

ANTONIO: Pues utilice el teléfono, que su madre lo agradecerá. Y nada de salir a sitios de Carabanchel y esos pueblos. Usted vaya con Zubeldía y con su cuadrilla.

JARDIEL: (Muy nervioso.) ¿Cómo sabe que...?

ANTONIO: Aquí en la capital se saben todas las cosas, hay que cuidarse de los subversivos que siempre están tramando algo... en esos sitios no va a encontrar usted nada bueno. Hágame caso. No querrá usted juntarse con gente con la que no debe juntarse...

(Entra TOPETE.JARDIEL permanece atónito, sin poder articular palabra.)

TOPETE: Perdón, ¿ime permiten?... Don Antonio, ¿ile digo que entre?... está abajo... Don Adolfo.

ANTONIO: Sí, Doña María, el teniente Jardiel ya se marchaba.

JARDIEL: Sí, Directora... perdóneme Don Antonio. No volverá a ocurrir. Se lo prometo...

ANTONIO: Llame, llame a Zubeldia, ya verá, ya, que ése es buena pieza... (Sonríe.) Es una orden.

JARDIEL: Descuide, descuide que lo haré.... Y no se preocupe que...

ANTONIO: Tranquilo, tranquilo...

(Sale TOPETE.)

ANTONIO: Busque a Herr Mayer, esta mañana quería realizar pruebas con cardiazol, quiere llevarse un estudio a Alemania.

JARDIEL: Perdóneme, Don Antonio.

ANTONIO: Nada de perdones, trabajo y trabajo. ¿Quiere usted conocer a Don Adolfo?, es un héroe...

JARDIEL: No, bueno ya nos conocimos el otro día, prefiero...

ANTONIO: Un devoto del trabajo, así me gusta. 
(Sale JARDIEL. Entra TOPETE con ADOLFO. ADOLFO y JARDIEL se miran y bajan la vista.)

JARDIEL: Buenos días.

ADOLFO: Buenos días.

TOPETE: Don Adolfo, le presento a nuestro eminente Catedrático Don Antonio VallejoNágera... ya sabe usted quién es Don Adolfo.

ANTONIO: (Levantándose.) Por supuesto, Doña María, y es un honor para mí conocerle. Pocas veces se tiene la oportunidad de estrechar la mano de un héroe de guerra ( $S e$ dan la mano.)

ADOLFO: El honor es mío.

TOPETE: Bueno, si necesitan algo estaré en despensa.

ADOLFO: Gracias Doña María.

(Sale TOPETE.)

ANTONIO: Siéntese Don Adolfo, por favor. Perdone por el desorden, pero aquí no tengo despacho, solo vengo de visita alguna que otra vez y Doña María, muy amablemente, me deja utilizar el suyo.

Adolfo: Me siento un imbécil, Don Antonio... molestarle, con lo ocupado que debe estar... para una cosa tan nimia, tan...

ANTONIO: ¡Cómo!, lo que está haciendo gente como usted, Don Adolfo, es precisamente llevar a la práctica la prístina visión de nuestro Caudillo... ¿ ¿Nimia?, el futuro de la Raza depende de estas acciones... (Sonríe.) Permítame, Don Adolfo, ¿cómo fue aquello de El Alcázar?

Adolfo: No, Don Antonio, no se crea las mentiras del cine... ésa película... Fue duro, pero... jesa película!... ya sabe, lo adornan todo...

ANTONIO: Ustedes fueron todo un símbolo. Esa película no ha hecho más que contar la realidad, la gente necesita héroes, ahora más que nunca.

AdOLFo: Vuelvo a darle las gracias, Don Antonio... Fue duro, pero no me gusta hablar de ello, nadie quiere saber la verdad realmente, todo se ha inflado como un globo... Todos empiezan a hablar de héroes y... bueno, ya sabe. Simplemente cumplimos con nuestro deber. ¿ ¿Le molesta si...? (Saca un cigarrillo.)

ANTONIO: Ve como es usted un héroe...Sí, por favor, fume... fume... (ADOLFO busca el mechero y enciende un cigarrillo.) Ya me ha comentado Doña María... No tiene por qué preocuparse, Don Adolfo, le doy mi palabra de que no existe ningún Gen Marxista. Ser marxista o demócrata no es más que una desviación, un asunto 
ambiental. Un bebé criado en un hogar cristiano, ético y nacional, como lo es el suyo, nunca va a desarrollar ningún problema. Es imposible.

ADOLFO: Si ya lo sé pero, es mi mujer, en realidad... usted como psiquiatra... No consigo hacer que entre en razón. Siempre con lo de que está yerma, seca. ¿Sabe?, perdimos un par de niños, al nacer. Nacieron muertos y es como si no pudiera quitárselo de la cabeza. Ni siquiera sé si es bueno adoptar otro. No sé si le hará bien...

ANTONIO: Le hará bien, Don Adolfo. Imagínese que usted no pudiera hacer lo que hace un hombre, pues piense cómo se debe sentir ella al no poder cumplir con su sagrado deber. Si lo desea, para mí sería un honor hacerles una visita y...

ADOLFO: ¿Lo haría?

ANTONIO: Con mucho gusto. Como ya le he dicho, España y yo le debemos más de lo que se imagina. Además, me gustaría también contar con usted, que conociera a algunos colegas... Nos ronda una idea desde hace unos meses y, alguien como usted, también sería de gran apoyo.

Adolfo: Cuénteme...

ANTONIO: ¿Qué le parecería proponer a nuestro Caudillo la restauración de la Inquisición?... no, no se asuste, hablamos de una empresa moderna, con otra orientación y, por supuesto, otros medios. Pero Inquisición al fin y al cabo. Como un cuerpo vigilante que detenga las ideas extranjeras, que vuelva a instaurar los valores de la Hispanidad. Y acabar de una vez por todas con esa Anti-España.

ADOLFO: Una idea necesaria, cuente con mi apoyo. Pero...

ANTONIO: No sé si el proyecto llegará a algún puerto, pero no está demás intentarlo. Hay tantas cosas por hacer... y con apoyos como el suyo, de un héroe de nuestra Cruzada...

ADOLFo: (Apaga el cigarrillo.) Por supuesto que sí.

ANTONIO: (Escribe algo en un papel.) Le diré a Jardiel que le dé esto (Le acerca el papel.) Para su mujer. Una antes de acostarse y empezará a ver el mundo un poco mejor por la mañana. Ya verá, ya... un niño es luz, es alegría, es vida. El instinto femenino se activa como un resorte. En cuanto su mujer oiga llorar al bebé se sentirá completa (Coge el teléfono) Sí, que se acerque Jardiel al despacho.

ADOLFO: No, no hace falta que le moleste, hablo con Doña María y...

ANTONIO: No es molestia, Jardiel es de toda confianza.

(ADOLFO se levanta. ANTONIO también. Se estrechan la mano.)

ANTONIO: Seguro que esto no es más que el comienzo de una larga relación de amistad.

AdOLFO: Sería un placer. 
(Entra JARDIEL.)

ANTONIO: Tome Jardiel, estas recetas. Lleve a Don Adolfo a la farmacia y que se lo den sin rechistar.

JARDIEL: A sus órdenes Don Antonio. Por cierto, me ha dicho Herr Mayer que si podría acercarse a Enfermería, es por Carmen, que anda armando jaleo como siempre...

ANTONIO: Tiene usted que aprender alemán, Jardiel, ese es el futuro... Lo dicho, Don Adolfo, le dejo en buenas manos. Atiéndale, Jardiel, en todo lo que necesite.

ADOLFO: Gracias, Don Antonio.

(ANTONIO sale. Los dos se miran y JARDIEL corre a cerrar la puerta. Se acercan y se besan apasionadamente en la boca. Se manosean apresuradamente, vigilando la puerta.)

JARDIEL: No te ha dicho nada.

ADOLFO: ¿Qué me iba a decir?

JARDIEL: Creo que me ha estado siguiendo el muy cabrón. Mi madre... esa puta metomentodo, ya sé porqué quería traerme a Madrid.

ADOLFO: ¿A Carabanchel? Coño, Jardiel, pero si fue una casualidad que nos encontráramos allí. ¿Cómo va a saber nadie que yo...?

JARDIEL: Ándate con ojo los días que estés por aquí... haz que venga tu mujer a Madrid.

ADOLFO: Pero ella...

JARDIEL: Hay que avisar a todos los que estaban la otra noche... i ca cuántos conoces?

ADOLFO: No sé, a uno o dos, los demás llevábamos máscaras cuando entramos, no sé... (Ríe.)

JARDIEL: Bueno, dame el papel... te lo firmo y se lo das a las de farmacia. Si hay algún problema que hablen con la directora (Lo firma.)

Adolfo: (Sensual.) ¿ ¿Te vas? ¿Asî?

JARDIEL: Aquí no, coño... la puta de mi madre, le hubiera encantado que fuera yo y no mi hermano el que palmara en la guerra, mi hermano siempre fue un mierda, como mi padre... si se entera Don Antonio me manda fusilar.

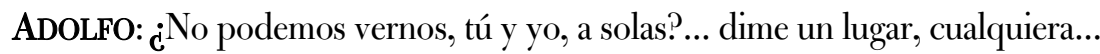

JARDIEL: No sé, déjame pensar, déjame pensar... el muy cabrón...

(Se besan y se hacen unas caricias rápidas y furtivas. JARDIEL sale. ADOLFO se enciende un cigarro y sonríe.) 


\section{Escena VI}

(En la celda. CARMEN está peinándose con un espejo imaginario. Canta.)

CARMEN: Vengo caminando,

hace tiempo que no miro tus vestidos,

Hace tiempo que pisamos

las flores y el silencio.

Hace tiempo que la vida son retales

que prometimos no olvidar

${ }_{\mathrm{C} T e}$ acuerdas de cuando las horas

eran de tomillo y campo,

de luna llena y verano,

del olor vendimia?

Hoy sólo quiero adivinar:

¿por qué ya no me nacen

más canciones?

$\mathrm{Y}$ asomarme a tu ventana,

como dos adolescentes.

Y odiar la mañana

que nos quita la noche

$\mathrm{y}$ trae los pasos de la gente.

Con aquel vestido blanco,

y tu labios de colores, 
tu madre te llenaba siempre

el cabello de flores.

Como caer en un pozo

donde las palabras ya no sirven.

Observar

como si el mundo fuera ajeno

a mi respiración.

Como estar tendido en el tiempo,

como el agua sin corriente,

como no amanece...

Hoy sólo quiero adivinar:

¿por qué ya no me nacen

más canciones?

\section{(Entra JARDIEL.)}

CARMEN: ¿ $\mathrm{Y}$ Ya es invierno?

JARDIEL: No, todavía no. Aún queda mucho, unas semanas...

CARMEN: A mí me gusta el invierno, el fuego, el olor a madera. ¿Ha visto a mi niño?, hoy no le he dado de mamar. Mire (Se saca un pecho y aprieta el pezón.) Tengo mucha leche y tengo miedo a que se pudra dentro. ¿La leche en qué se convierte cuando no se da a nadie?

JARDIEL: Tápese, Carmen, tápese. No se preocupe por eso. ¿iHa pensado en lo que le dije?, no puede usted ir por ahí enseñando los pechos a todos los hombres...

CARMEN: ¿Quién es usted?... ¿ ¿es el verdugo?... ya me toca... A todas les toca cuando sus hijos no lloran más.

JARDIEL: ${ }_{\mathrm{i}}{ }^{\text {No }}$ se acuerda de mí?... Carmen, llevamos varios días viéndonos.

CARMEN: Remedios dice que mi hijo es un trapo.

JARDIEL: A ver, Carmen (Saca unas hojas con dibujos de la carpeta.) ¿Se acuerda de estos dibujos?... (Le muestra uno.) ¿Qué ve aquî?

\section{(CARMEN mira la hoja y la escupe.)}

JARDIEL: No empecemos, Carmen...

(CARMEN canta al trapo como si estuviera en otro mundo.) 
JARDIEL: Si sigue así le voy a quitar el trapo.

CARMEN: El rojo es a la sangre lo que el amarillo es a... $\mathrm{c}$ Es invierno, ya?... los rojos somos amarillos, como la sangre, como el pus... Ave María Purísima, sin pecado concebido, Ave María Purísima, amarilla como los rojos, amarilla, roja, amarilla, roja, roja, Virgen roja, puta María, Virgen roja...

JARDIEL: No la creo, Carmen, no la creo... Creo que es usted muy lista. Que se hace pasar por loca pero que nos está tomando el pelo a todos, incluso a su compañera. Sí... Eso dice ella... ¿ ¿Ah? ¿ ¿No se lo ha dicho?... Ella anda diciendo por ahí que usted toma el pelo a todos... que está cuerda, que sólo hace esto para que la dejen salir al psiquiátrico... Sí, eso dice Remedios, que usted le toma el pelo también a ella, pero que no está loca... ¿qué le parece?

CARMEN: Ella es una puta, ¿ise lo ha dicho?... El jardinero le hace favores y ella es puta para las dos... Pero ella no dice eso, ella me quiere... es una puta, es una puta... ¿ d $^{\text {la }}$ Virgen era puta también?... Ella me quiere... (Al trapo.) ${ }_{\mathrm{C}}$ Verdad mi amor?... Ella nos quiere...

JARDIEL: Venga, Carmen... vale. Mire... Hagamos un par de test y le traigo una magdalena... De verdad, han traído un par de cajas de un convento de Ávila, y unas yemas... Seguro que hace mucho que no toma dulce... Y el dulce es bueno para la leche...

(CARMEN le enseña los pechos desnudos.)

CARMEN: Yo no soy una puta... ¿Quiere tocarlas?... Antes todo el mundo quería tocarlas... ahora están podridas... Pero dan leche, leche podrida... la Virgen daba leche podrida, por eso le mataron al hijo, porque estaba podrido...

JARDIEL: Vístase, Carmen, por favor...

(JARDIEL Intenta ayudarla, pero CARMEN le coloca las manos en sus pechos y las aprieta fuerte, mirándole a los ojos.)

(Entra TOPETE y se sorprende al ver la escena. JARDIEL puede apartar las manos de los pechos de CARMEN, pero espera unos segundos para asegurarse de que la Directora le vea.)

TOPETE: ¿Qué? ¿Se hace con ella?

JARDIEL: Es imposible... le juro que...

TOPETE: No es usted el primero, Carmen es muy lista. 
JARDIEL: No sé, Doña María, creo que hay algo de verdad en todo lo que hace. He estado echando un vistazo a algunos los informes y... hay cosas que no cuadran. Esta mujer necesitaría estar en el psiquiátrico no aquí...

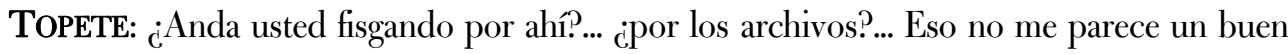
plan, Don Jardiel, por mucho que usted sea quien es... aquí hay unas normas y... Si quiere saber algo, pregúnteme a mí, yo aquí veo y oigo todo. Todo. Esa es mi labor. Hay que tener cuidado con tanto rojo suelto por ahí, una no puede fiarse de nadie.

CARMEN: ¿Han traído ya a mi hijo?... (Canturrea.)

TOPETE: Carmencita, tienes que colaborar con este buen señor... a no ser que quieras ir al cuarto.

CARMEN: No quiero ir al cuarto.

TOPETE: Venga, toma esto, que te he traído unos calmantes de parte del señor que vino el otro día...

(TOPETE saca una pastilla. Le tapona la nariz a CARMEN y le abre la boca para metérsela. Espera a que se la trague, comprueba la boca bien vacía y la vuelve a dejar con su trapo.)

JARDIEL: ¿No tiene familia aquí?

TOPETE: No sé, en su tierra a lo mejor, pero con tanta guerra... no le sé decir... ¿imando entrar ya a la otra?

JARDIEL: Sí, por favor.

\section{(TOPETE sale a buscar a REMEDIOS y entra con ella.)}

TOPETE: Bueno, Teniente, yo les dejo... que tengo mucha faena. Y tenga cuidado con Remedios, que no respeta ni el embarazo.

JARDIEL: Bien, bien, gracias por todo y... no se preocupe que... no era mi intención...

TOPETE: Por supuesto, Teniente, entiendo su dedicación... usted comprenderá que tengo que cuidar de esta institución... A partir de ahora cualquier información que usted quiera yo se la daré gustosa, pero nada de ir por ahí revolviendo papeles que luego... imagínese que todo el mundo hiciera eso... esto sería un sin sargento.

JARDIEL: No volverá a ocurrir, se lo prometo.

\section{(TOPETE sale.)}

JARDIEL: Hola Remedios, me alegra que haya accedido voluntariamente a hablar conmigo, en su estado... 
REMEDIOS: (Se acerca.) Yo, por un vaso de leche le hago lo que sea... voluntariamente.

JARDIEL: Es usted muy razonable. ¿ $\mathrm{H}$ a pensado en la conversación que tuvimos el otro día?

REMEDIOS: Sí, claro, no tengo otra cosa que hacer. ${ }_{\mathrm{C}} \mathrm{Ha}$ visto a los niños de la sala de lactancia? ${ }_{\mathrm{C}} \mathrm{Ha}$ visto cómo lloran?... Solo dejan entrar a las madres una hora al día a dar el pecho. El resto del tiempo... ahí tirados: cagándose y llorando.

JARDIEL: ¿Lo sabe la directora?

REMEDIOS: ¿Ésta? ¿La Topete? (Ríe.) ¿ De quién se cree que es la idea?

JARDIEL: No entiendo como usted, siendo tan lista... está aquí. ¿Qué hizo en la guerra?

REMEDIOS: (Ríe.) ¿Qué hizo usted?

JARDIEL: Luchar por España, ayudar a los soldados en el frente.

REMEDIOS: Lo mismo que yo.

JARDIEL: (Sonríe.) Bueno, ¿y?... Sí, de lo nuestro...

REMEDIOS: Que lo he pensado y... ¿ Usted cree que en mi situación puedo elegir?

JARDIEL: ¿A qué se refiere?

REMEDIOS: Bueno, a mí no me venga con ese aire de mosquita muerta... usted está aquí, como todos... para curarnos, no te jode... (Ríe.)

JARDIEL: ¿Qué quiere? ¿Algo a cambio?

REMEDIOS: Ahí quería yo llegar... usted quiere que le ayude, ¿no? Pues yo quiero que usted me ayude a mí... Aquí los niños desaparecen, desaparecen o se mueren. Y yo quiero que la mía nazca fuera, que me lleve usted a Ventas. Yo le ayudo, hablo con las presas, respondemos a sus preguntas, vemos sus dibujitos... y usted hace que nuestros niños vivan, ¿ile parece?

JARDIEL: Creo, Remedios (Suspira y piensa.) Esto que me está contando es un poco... tiene usted mucha capacidad de inventiva. Los niños mueren por las condiciones... por la precaria salud de sus madres. Además, ¿quién va a querer llevarse a los hijos de las presas?

REMEDIOS: Si quiere nos seguimos haciendo las tontas, como el otro día, que ya me sé yo esas visitas... Sí, esos tipos que vienen a vernos como a las mulas, a ver si parimos bien para llevarse a los niños. Que ya lo he visto muchas veces...

JARDIEL: (Hace un gesto de silencio señalando a CARMEN.) Tenga usted cuidado con esas cosas... Ésa es una acusación muy grave.

REMEDIOS: Bueno, ¿'me ayuda o no?

JARDIEL: Con medida, Remedios, con medida.

(CARMEN ha vuelto a sacarse los pechos y dice cosas sin sentido casi en un susurro, algo drogada por la pastilla. JARDIEL se acerca a CARMEN para taparla pero REMEDIOS se interpone y la viste.) 
REMEDIOS: ¡No se preocupe por ésta!, si le acaban de dar la pastilla... ahora se queda inútil hasta mañana... mejor así, cuanto más inútil menos se entera...

JARDIEL: No sé por qué tiene esa manía de sacar los pechos...

REMEDIOS: (Ríe.) ¡Ah!, ¿ ¿no es usted hombre? Aquí vienen... bueno... ya me entiende. Es lo

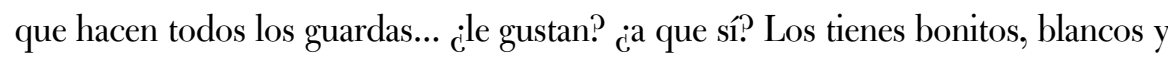
rosados. Aunque se le pudren los pezones, que su leche está mal, que no tiene vitaminas.

JARDIEL: Me estoy hartando de su desorbitada querencia sexual.

REMEDIOS: Ya, pues debe ser el único... Llevo de calabozo en calabozo desde hace dos años y me han violado de todos los colores. Los peores son los moros. Cuando vinieron... Esos te pegan hasta que no puedes más, peor que en Gobernación. No se haga el tonto... yo era la que más me resistía hasta que me dieron lo de las descargas ahí abajo, ahí me dije: "Remedios, te van a matar" y hala, pero no dije ni una palabra, eso nunca... yo lo único que quiero es que mi niña salga de aquí y se vaya con mi Martín, él es bueno, no sabe mucho, pero es bueno. Que conozca a su hermana y viva fuera. No quiero que me la roben y se la den a unos fascistas hijos de... bueno, ya me entiende.

JARDIEL: Eso no pasa, mujer. Y no hable así, que ya sabe quiénes son los míos... Eso son fábulas que corren por todas las cárceles.

REMEDIOS: Ya, pues por eso. Que usted no es igual, que usted es médico, que se le ve... que no nos mira... que usted nos mira a los ojos... Bueno, ¿qué? ¿ंMe ayuda o no?

JARDIEL: Me alegro de que confíe en mí.

CARMEN: ¿Ya es invierno?, el rojo es a la sangre, el amarillo es al invierno...

REMEDIOS: ¿ $\mathrm{i}$ e?, no le haga más preguntas tontas de esas, que luego se pasa todo el día repitiéndolas...

JARDIEL: No sé, déjeme pensar... está bien, suponiendo que aquí ocurran esas cosas increíbles que me cuenta... ¿ ¿Pondría a mi favor a todas las presas para realizar los estudios?... Eso me sería de gran ayuda, tenga en cuenta que voy a estar solo unas semanas aquí...

REMEDIOS: Yo le digo que hablo con ellas y hacemos sus estudios. Pero usted se encarga de sacar a mi hija y contarle esto a los de la Cruz Roja.

JARDIEL: Veré lo que puedo hacer, usted cumpla y yo cumpliré.

REMEDIOS: Yo siempre cumplo.

JARDIEL: Carmen es comunista y usted anarquista, lo he leído en los informes, cipor qué se ayudan tanto?

REMEDIOS: Aquí ya no somos más que mujeres.

JARDIEL: Ya... 
(Entra Don ADOLFO.)

REMEDIOS: Hombre, Don Diplomático, ¿cómo usted por aquî? Que ha venido, ¿̇a ver mi dentadura?.. Mire, mire (Le enseña los dientes.) A ver si encuentra algo de carne, del filete que me han dado...

ADOLFo: Qué cosas tiene, ¿Qué? ¿Les tratan mejor?

REMEDIOS: Claro, como en un chalé, no es ahí donde dicen que estamos...

(JARDIEL coge aparte a ADOLFO.)

JARDIEL: Tiene usted que marcharse.

ADOLFO: Sí, si precisamente venía yo a buscarle a usted para lo de mi mujer, el asunto de las jaquecas que...

JARDIEL: Bien, acompáñeme y lo solucionamos...

(JARDIEL y ADOLFO salen.)

REMEDIOS: ¿Has visto?, así es como se sacan las cosas... Éste entra... ya verás... Si no hay más que verle, que no es trigo limpio.

CARMEN: Yo no te voy a dejar mi trapo...

REMEDIOS: Mira tonta, que eres muy tonta, que las cosas malas no duran siempre. ¿Quieres que te baile?

CARMEN: Sí, por favor... cántame esa que me gusta.

REMEDIOS: Pero me haces caso, que nunca me haces caso.

CARMEN: Eres una puta.

REMEDIOS: Ya, y tú deja de enseñar las tetas a todos, que ya no te van a pegar más, que ahora todo va a cambiar...

(REMEDIOS baila y le canta una canción, como puede, a CARMEN.) 


\section{Escena VII}

(Despacho de MARÍA TOPETE.)

TOPETE: Sí, de eso no se preocupe, lo mejor es que lo deje todo en nuestras manos, ya verá, Dios siempre está con el desfavorecido. En unas semanas tendremos todos los papeles de la Dirección Provincial.

MARTín: ¿Y el nombre? ¿Eso quién lo va a elegir?

TOPETE: El del día, de eso no tiene que preocuparse.

MARTín: Yo lo que no puedo es perder ninguna mañana más, ya sabe... acabo de entrar de mancebo, en una farmacia y tengo que echar muchas horas. Si falto, pues...

TOPETE: No se preocupe, pierda cuidado, Martín. Nosotros haremos todos los trámites y en poco tiempo tendrá usted a su pequeño en casa.

MARTín: (Sacando un papel.) Mire, Señora Directora, este papel es de mi primo... me ha dicho que si pudiera usted leerlo pues...

TOPETE: Si por eso he aceptado verle, Martín, por su primo, que ha removido Roma con Santiago para interceder por Remedios. Pero ya sabe usted cómo están las cosas. Ahora no se dan indultos así como así... y más con su pasado. Pero yo lo intento, de verdad. Que tiene usted muy buenos contactos.

MARTín: Lo siento Señora Directora, por la cantidad, no he podido conseguir más. Es el adelanto de sueldo, del señor Remigio de la farmacia, que se lo pagaré a semana en un año, es que la cosa está como está... y una boca más, pues no sé a dónde vamos 
a ir a parar. Que una boca más es una boca más. Quizá estaría mejor aquí, que esta cárcel parece un chalé, aquí los niños seguro que están mejor que fuera...

TOPETE: No se preocupe, Martín, este dinero seguro que ayuda, ya verá, usted pida a la Virgen de los Desamparados, que ella siempre escucha.

MARTín: Yo lo hago, Señora Directora, yo lo hago, pero ya sabe usted... que a lo mejor no lo hago bien, que yo esto del rezo nunca lo he hecho y...

TOPETE: Por eso estamos como estamos.

MARTín: Le doy las gracias (Se levanta.) ¿Y el Auxilio Social?, es que mire usted, no es que no quiera al niño, o a la niña, que venga, pero fuera estamos achuchados... ya sabe que tenemos otra hija, que no salió bien, que tiene esos problemas... y ahora pues otra boca... ya me entiende...

TOPETE: Ya le he dicho que la adopción es una buena acción en estos casos... De todas formas, ya sabe que aquí, por los problemas de humedad muchas criaturas mueren al poco de nacer...

MARTÍn: No sé, ¿ ¿usted qué me aconseja?

TOPETE: ¿Ha hablado ya de esto con Remedios?

MARTín: No, ella no sabe nada de esto, ni quiero que lo sepa... ¿ ¿sabe algo de su condena?

TOPETE: Desde aquí no podemos hacer mucho, yo pido por su alma si tiene que ir con el Señor... pero su... mujer... ha hecho mucho mal, usted lo sabe...

MARTín: No puedo traer más dinero, se lo prometo... si pudiera, pero...

TOPETE: No prometa, jure. Las promesas se las lleva el viento pero los juramentos los escucha el Señor.

MARTín: Muchas gracias, Señora Directora, ¿ ¿usted cree que estoy haciendo bien?

TOPETE: No tiene por qué darlas, usted está haciendo lo correcto, ojalá todos los rojos hicieran este acto de constricción que usted está haciendo. Ya que ustedes se han descarriado no tienen que dejar que sus hijos continúen con su pecado. Así, a lo mejor se gana un sitio en el cielo, que está lleno de arrepentidos...

MARTín: Bueno, usted ya me dice... Gracias, muchas gracias.

(MARTÍN sale. TOPETE mira el papel que ha firmado MARTÍN y lo guarda en el cajón.)

TOPETE: ¿Qué le trae por mi despacho? Últimamente no paro de recibir visitas.

JARDIEL: Bueno, el otro día me quedé un poco... no sé... quería aclarar alguna cosa por si...

TOPETE: De ninguna manera Jardiel, no hay nada que aclarar, soy yo la que le tiene que pedir disculpas. Si usted quiere mirar los registros yo encantada se los ofrezco, usted pídamelo y estoy a sus órdenes.

JARDIEL: Ya sabe, es que no me acostumbro a los fusilamientos. 
TOPETE: Nadie se acostumbra a esas cosas, yo tampoco. Siempre acabo cogiendo cariño a alguna presa o a algún crío y luego... Pero esas penas de muerte sirven de escarmiento a las demás. De algún modo tienen que purgar sus pecados. Hicieron mucho mal... mucho mal.

JARDIEL: ¿Es verdad eso que dicen que estuvo usted en la cárcel?

TOPETE: No me gusta hablar de esas cosas pero sí, ya pasé mi martirio y nunca renegué de mi fe, por eso tengo que ayudar a esas milicianas a encontrar lo que perdieron. Son como el diablo, pero el diablo también es hijo de Dios.

JARDIEL: Debió ser terrible, si quiere un día puedo... tratarla, por si tiene algún problema de sueño... es frecuente en estos casos.

TOPETE: Yo ya hablo con Dios todas las noches, Él es mi confesor.

JARDIEL: Bueno, yo solo quería ofrecerle mis servicios. Durante la guerra ayudé a mucha gente que, digamos, lo había pasado mal. En el frente se sufre mucho, igual que en las cárceles, imagino.

TOPETE: Se lo agradezco, Teniente, es usted un digno ayudante del Doctor. Ahora si me permite... (MARÍA TOPETE se levanta y mira por la ventana.)

JARDIEL: Por supuesto, Doña María, perdóneme... no quiero distraerla de sus labores (Se levanta.)

TOPETE: Mire, ese jardinero es todo un artista... Cipriano, tiene unas manos...

JARDIEL: Es un gusto pasear por el jardín...

(Miran por la ventana unos segundos.)

TOPETE: Tenga usted cuidado Jardiel, con esas rojas, son sibilinas, como todas las mujeres. No se implique, Dios las perdonará cuando sea preciso, pero no se crea todas esas cosas que dicen.

JARDIEL: El otro día, con Carmen, no piense que... yo...

TOPETE: No se preocupe... Carmen... ésa es la peor de todas. Y usted, al fin y al cabo, es un hombre. Es normal... no es culpa suya. La virtud está en reflexionar sobre lo que hacemos, después de hacerlo, y así darnos el castigo justo... Esa Carmen está perdida, ni se imagina lo que hizo en la guerra. Era como Belcebú.

JARDIEL: Para mí solo son sujetos de estudio.

TOPETE: Y eso deben ser... Haga caso al Doctor, él es una eminencia... Quede con Dios, Don Jardiel.

JARDIEL: Buenos días, Doña María.

(Sale JARDIEL.) 


\section{(Entra ADOLFO.)}

TOPETE: Buenos días, Don Adolfo ¿iNecesita algo? Últimamente está mucho por aquí, estará impaciente, ${ }_{\mathrm{C}}^{\text {no? }}$

AdOLFO: ¿Puedo? (Señala la silla.)

TOPETE: Sí, como no.

(ADOLFO se sienta.)

ADOLFO: ¿Cómo va la cosa? ¿Ha ingresado otra?

TOPETE: Espere que mire... (Abre el registro.) No, parece que no tenemos suerte. Las cosas en Ventas están como están, quizá si se espera unos meses...

Adolfo: No lo veo claro, como decirle, yo sé que esa mujer ha hecho muchas cosas pero quizá... a mí me parece que tiene energía, me gusta esa fuerza que tiene... bien canalizada...

TOPETE: Pues, usted me dirá...

ADOLFO: Nada, simplemente pasaba por aquí y me he acercado. Estos días tengo que visitar unas fábricas que están aquí al lado y...

TOPETE: Hace bien, Don Adolfo, su visita siempre es un chorro de aire puro, pero debe usted tener paciencia.

\section{(Entra JARDIEL.)}

JARDIEL: Doña María... Es Don Antonio, que viene a hacer unas gestiones.

TOPETE: No, si Don Adolfo ya se iba...

Adolfo: ¡Oh, sí! Ya me iba, solo... Por cierto Jardiel, muchas gracias por los medicamentos. Se los he enviado a mi mujer.

JARDIEL: Pensé que ella iba a venir a Madrid...

ADOLFO: Bueno, ya sabe, no se encuentra del todo bien, el ajetreo del viaje...

(ADOLFO se levanta y sale.)

ADOLFO: Buenos días.

TOPETE Y JARDIEL: Buenos días, Don Adolfo.

TOPETE: Está muy nervioso, con todo esto del niño. Su mujer, además, que tiene esos mareos la pobre...

JARDIEL: Sí, ya me ha dicho Don Antonio, no va a encontrar familia mejor... 
(Entra ANTONIO.)

ANTONIO: Buenos días nos dé Dios.

TOPETE: Don Antonio, aquí tiene mi despacho para lo que usted precise.

ANTONIO: Nada, Doña María, ya sabe... los asuntos, siempre de aquí para allá. ¿Podría dejarnos hablar a solas un instante?

ToPETE: Como no, esta es su casa, además ya me iba que tengo que preparar unas cosas.

ANTONIO: Gracias, Doña María, es usted un sol, como siempre...

(TOPETE sale.)

JARDIEL: Usted me dirá, Don Antonio.

ANTONIO: Buenas noticias, Jardiel, buenas noticias... Parece que nuestros colegas alemanes están muy contentos con los resultados de los estudios. Eso nos puede traer un empuje a nuestro propósito.

JARDIEL: Eso es muy interesante, Don Antonio, realmente puede dar un impulso a nuestros estudios y que tengamos más tiempo... yo no soy partícipe de las conclusiones precipitadas.

ANTONIO: Por eso... por eso le he propuesto a usted para que vaya a Alemania el mes que viene si todo va como tiene que ir, quizá conozca al mismísimo Himmler. Wie sprechen Sie Deutsch?

JARDIEL: Gut, gut, mein Kommandant... mejorando. No sé qué decirle, Don Antonio... últimamente los acontecimientos me sobrepasan. Estoy...

ANTONIO: Su trabajo con las presas está siendo excelente, mejor de lo que cualquiera podría esperar.

(ANTONIO se acerca a la puerta para cerciorarse de que está bien cerrada.)

ANTONIO: ¿Ha estado con Zubeldía?

JARDIEL: Śí, hemos estado de cuadrilla estas últimas noches.

ANTONIO: Así me gusta, que luego no me diga su madre que no me ocupo de usted como de un hijo.

JARDIEL: Mi madre...

ANTONIO: ¿Qué le pasa, Jardiel... Teniente? Tiene usted que estar más contento. Hay un nuevo futuro a la vuelta de la esquina y usted va a ser uno de los protagonistas.

JARDIEL: Mi padre siempre ha pensado en mí como en su fracaso, siempre quiso que fuera como mi hermano... pero yo no soy como él. 
ANTONIO: Cada uno es lo que es, su madre le quiere y sólo quiere lo mejor para usted. Su padre... por eso quiero llevarle por el buen camino. En la vida sólo hay dos caminos: el correcto y el desviado, todos podemos jugar en un momento dado, incluso dejarnos arrastrar por la mala vida pero...

JARDIEL: Yo quiero hacer lo correcto.

ANTONIO: Pues entonces no tiene de qué preocuparse. Menudo elemento ese Zubeldía, le llevó a...

JARDIEL: ¡Don Antonio!... esas cosas... (Sonríe.)

ANTONIO: Ustedes son jóvenes, tienen que desfogarse, y para eso están las fulanas... Hay que probarlo para luego ser un buen padre y para no querer que nuestras hijas se desvíen.

JARDIEL: Tiene usted toda la razón, como siempre, Don Antonio. Es usted como un padre para mí... Don Antonio, $\dot{c}^{\text {a }}$ usted no le afectan estos niños?, llevo días despertándome por las noches. Sueño con sus ojos, con sus gritos... lo siento Don Antonio, a lo mejor no estoy preparado para este trabajo.

ANTONIO: Acuérdese de la guerra Jardiel, hay que templarse. Pregunte al profesor Mayer. Estamos construyendo el futuro, como le decía... ¿Se imagina una nueva raza de niños españoles puros? Seleccionando a los padres. Ya lo están haciendo en Alemania, el proyecto Lebensborn lo llama el mismísimo Himmler. Imagínese, sin judíos, masones, moros, sólo sangre española, católica y pura.

JARDIEL: Estoy emocionado, Don Antonio, simplemente no quiero defraudarle, no me lo perdonaría...

ANTONIO: Usted escoja el camino recto, ya me entiende. Madrid es muy pequeño, es como un pueblo, aquí nos conocemos todos. Búsquese una buena mujer, dele a su madre unos cuántos nietos y haga carrera.

JARDIEL: Lo haré, Don Antonio, lo haré, precisamente el otro día, en un café del centro con Zubeldía, conocí a una chica de buena familia, tomamos un café y...

ANTONIO: Nada, tráigala a cenar a casa si se formaliza. ¿Me hará usted el honor?

JARDIEL: Estamos sólo hablando todavía.

ANTONIO: Muy bien, teniente, veo que me entiende. Usted forme una familia y haga bien su trabajo, del resto me ocupo yo, por lo que le debo a sus padres.

JARDIEL: Es usted como un padre para mí.

ANTONIO: Ya...

(ANTONIO sale. JARDIEL queda pensativo y sonríe, poniendo los pies encima de la mesa.) 
Rubén Buren

\section{Escena VIII}

(Dando un paseo vigiladas por CIPRIANO, fuera de escena, que intenta arreglar unas tijeras de podar sin mucho éxito.)

REMEDIOS: Ves Carmen, así estamos mejor... que hoy luce el sol, a ver si se nos quita la humedad de los huesos. ¿Por qué no pones a tu hijo al sol, a ver si se seca un poco y...?

CARmen: El sol es bueno... Cántale el Cara al Sol al niño, para que se vaya acostumbrando...

REMEDIOS: Ya lo cantamos todas las mañanas en el comedor.

CARMEN: (Estira el trapo en el suelo.)

Mi niño juega en la arena

como una ola de mar,

juega en la arena

como la espuma blanca,

juega en la arena

como el viento blanco.

Un caballo grande galopa,

hasta enterrarse en el mar

juega en la arena 
como una ola blanca...

REMEDIOS: Se ha levantado coplera la niña...

CARMEN: ¡Qué sabrás tú!

REMEDIOs: Mira el Cipriano, que no deja de vigilarnos... (Grita a CIPRIANO.) ¿Por qué no te das una vuelta, Cipriano, y nos dejas solas un rato, anda? ¿ $\mathrm{O}$ qué te crees, que me voy a saltar la tapia con este bombo?... Que no nos movemos de aquí... mírale, ya se está relamiendo el muy cabrón.

CARMEN: Cipriano te quiere porque eres una puta.

REMEDIOS: Parece que estás mejor con esas pastillas... (Se acaricia la tripa.) Y esta que no sale, a mí ya no me cuadran las cuentas...

CARMEN: Los niños vienen cuando tienen que venir.

REMEDIOS: Este solecito da la vida, yo no puedo vivir sin sol, me recuerda a mi tierra. Como esos poemas que siempre dices... Blanco, las paredes blancas como mi pueblo... Yo nunca he montado a caballo, me daban miedo.

CARMEN: Los caballos son bellos.

REMEDIOS: Menos los que usaba la guardia civil... A veces echo de menos a mi niña, la de fuera, Libertad, hace más de dos años que no la veo.

CARMEN: Ese nombre no es bueno, no es bueno ese nombre...

(Pausa.)

REMEDIOS: A veces no sé qué diferencia hay entre nosotros y vosotros, aquí parecemos todas iguales... tanto discutir en guerra y luego...

CARMEN: Hay diferencia... Los anarquistas os creéis todo, que todo el mundo es bueno y eso no es verdad.

REMEDIOS: Eso será... Todavía no te he dado las gracias por salvarme la vida, nunca encuentro el momento, es como si no quisiera recordarlo. No te pasa a veces que hay cosas que no... pero, claro, claro que te pasa... (Sonríe.)

CARMEN: Eres una puta, por eso estamos vivas.

REMEDIOS: Yo te quiero, Carmen, por eso lo hago, eres mi única familia.

CARMEN: Y tú la mía, Reme, eres mi hermana.

(Pausa.)

(Entra ADOLFO.)

REMEDIOS: Este, ¿qué estará buscando?

CARMEN: Ya te dije que nadie da nada gratis. 
ADOLFO: Buenos días, señoras, ¿qué? ¿Al sol?

REMEDIOS: Ya ve, gracias a usted... venga Carmen, que hay que ir entrando, que si no el Cipriano se enfada y...

ADOLFO: Pueden quedarse un poco si quieren... ¿Cómo va? En breve ya...

REMEDIOS: Sí, en breve... ¡Cipriano! ¡Cipriano!

ADOLFO: ¿A qué tanta prisa?

REMEDIOS: ¡La Carmen, que se ha puesto indispuesta!... tanto sol... vamos para dentro.

ADOLFO: Buenos días, señoras, si necesitan algo ya saben...

REMEDIOS: Ya, ya sé, que usted es como la cigüeña, con la bolsa en el pico...

ADOLFO: (Ríe.) ¿A qué se refiere?

REMEDIOS: Vamos Carmen, vamos para adentro, que tiene pinta de llover en un rato...

CARMEN: Si hace sol y...

REMEDIOS: Por eso, porque hace sol, tira anda...

(Salen CARMEN y REMEDIOS. ADOLFO enciende un cigarrillo y se deja acariciar por el sol.)

(Al rato entra JARDIEL, visiblemente enfadado, mirando a los lados.)

JARDIEL: Pero, ¿qué cojones te he dicho? ¡Que no aparezcas por aquí!

ADOLFO: No sé, había pensado en... con este sol podemos...

JARDIEL: Mira, a mí no me jodas (Mira hacia los lados y le agarra para ir a una esquina, protegido por los árboles y el muro.) Lo que pasó, pasó, pero no va a volver a pasar... que ya me estás jodiendo con tanta persecución...

ADOLFO: Es como un juego, yo te pongo nervioso y así...

JARDIEL: (Saca una pistola y le encañona en la garganta.) ¡Que no me jodas! ¡Que te lo estoy diciendo por las buenas, puto héroe de los cojones!

ADOLFO: Tú no sabes quién soy yo, maricona, con una llamada te arruino la vida.

JARDIEL: ;O me dejas en paz o mando que te peguen dos tiros en una mierda de prostíbulo! ¡A ver cómo se lo explicas a tu mujer! ¡Les digo que dejen tu cuerpo donde tú ya sabes! ¡A ver qué dice la puta de tu mujer cuando te encuentren allí!

ADOLFO: Me gusta cuando te pones machote... quieres que lo hagamos aquí, en el jardín...

(JARDIEL le golpea. ADOLFO cae al suelo y JARDIEL le da un par de patadas en el estómago.)

JARDIEL: No me hagas repetírtelo...

(JARDIEL guarda la pistola y sale. ADOLFO, con dolor pero riendo, se coloca la ropa. Saca un cigarrillo. Se sacude, respira varias veces tocándose las costillas. Lo enciende y sonrí.) 


\section{Escena IX}

(En la celda.)

TOPETE: Tanto paseo... si fuera por mí no salíais más de una hora al mes, y con lluvia.

REMEDIOS: ¿Por qué nos odias tanto?

TOPETE: (Levantando la mano.) Háblame con respeto o te cruzo la cara. Animales, que no sois más que animales... Venga, Remedios, a la enfermería. Que hay que ver cómo van las cosas...

REMEDIOS: ¡Uy!, ahora hasta me miran el embarazo...

(Salen TOPETE y REMEDIOS.)

TOPETE: (Desde fuera.) Cipriano, quédese usted en la puerta para que no la arme hasta que venga el teniente Jardiel... Vamos, Remedios, no incordies más...

(Pausa. CARMEN se acerca a la puerta. Sonríe, se saca los pechos y susurra.)

CARmEN: Carmencita, Carmencita... ahora no hay quien te proteja... últimamente no colaboras mucho... tú y yo no podemos... ya sabes... intimar... Voy a tener que darte un correctivo. Cipriano... Cipriano... Tu Carmencita puta ya está preparada para el cinturón... ¿ ihoy no vas a darme cinturón?...

(EntraJARDIEL.) 
JARDIEL: Hola, Carmen (CARMEN no le mira, parece estar a punto de llorar.)

CARMEN: Hoy es domingo, los domingos hay merengue... Relacione los elementos: cuadrado, círculo, triángulo... el amarillo, el rojo, el verde... El fuego consume todo, como en el infierno, ya no hay infierno... el caballo grande...

JARDIEL: ¿Qué te pasa, Carmen? ¿Por qué Cipriano anda riéndose en la puerta?

\section{(CARMEN le enseña los pechos.)}

JARDIEL: Venga Carmen avancemos, tápese... no me voy a acercar, que ya sé lo que pasa.

CARMEN: No me quieres, yo no soy virgen, no soy pura, no me quieres...

JARDIEL: Carmen, Carmen... esa medicación le deja atontada, no sé si tengo que bajarle la dosis...

CARMEN: Aquí nadie sabe lo que es usted...

JARDIEL: Y, ¿qué soy?

CARMEN: Un caballo blanco, que galopa en la arena... yo sí sé lo que es, mi hermano era igual que usted. Él tampoco miraba a las mujeres...

JARDIEL: Pero, ¿qué dices Carmen?

CARMEN: El caballo blanco...

Mi niño juega en la arena

como una ola de mar,

juega en la arena

como la espuma blanca.

(CARMEN rodea a JARDIEL, cantando la canción con gestos amanerados de mujer.)

CARMEN: Un caballo blanco que galopa, que galopa... sin yeguas que le molesten... con las

flores, y las ramas... como la espuma suave... Suave como una pluma...

JARDIEL: (Enfadado.) ¿Qué? ¿Quieres que te haga lo que te hacen todos?

CARMEN: Sí (Le mira fijamente.) Sí, sí...

(JARDIEL tira sus papeles y se acerca. CARMEN se acerca y, arrodillándose, empieza a desabrocharle el cinturón. Se miran, ella le toca los genitales y le saca el pene.)

(Entra REMEDIOS.)

REMEDIOS: (Muy sorprendida y fuera de sí.) Carmen, Carmen... ¿ ite ha tocado ese cabrón?

CARMEN: El caballo blanco, el caballo blanco... 
REMEDIOS: ¡Malnacido! ¡Fascista hijo de puta!

(REMEDIOS se lanza a por JARDIEL pegándole. JARDIEL intenta sujetarla.)

REMEDIOS: ¡Qué has hecho medio hombre! ¡Que os lo dije a todos!, ¡que a mí solo y ella la dejáis en paz!

JARDIEL: Pero, ;qué dices!... ; Carmen está loca!

(REMEDIOS da un grito y se abalanza sobre él golpeándole. JARDIEL la tira al suelo bruscamente. CARMEN al ver a su compañera dolorida se lanza contra JARDIEL mordiéndole la oreja y gritando. JARDIEL se intenta zafar golpeando fuertemente a CARMEN, que parece disfrutar de la lucha. JARDIEL grita mientras su oreja sangra. REMEDIOS se toca la tripa gritando.)

JARDIEL: (Grita de dolor) ¡Sois animales! ¡Puta! ¡Me has arrancado la oreja! (Amenazando a REMEDIOs que permanece en el suelo gritando de dolor.) ¿Quieres más? ¿quieres que te mate el hijo a patadas? ¡Cipriano! ¡Cipriano! ¡Socorro!

(CARMEN intenta golpearle de nuevo pero él la agarra violentamente arrastrándola por el suelo.)

(Entra TOPETE.)

TOPETE: Pero, ¿qué está pasando aquí? (Saca la fusta y golpea a CARMEN.) ¡Sois como alimañas! (La golpea mientras CARMEN ríe y grita.)

REMEDIOS: ¡Que me la has matado! ¡Cabrón! ¡Que me la has matado! (Grita de dolor sujetándose la tripa, parece haber roto aguas.)

JARDIEL: ¡Son animales! ¡Voy a la enfermería!

TOPETE: ¡Ayúdeme! ¡Ayúdeme que ha roto aguas!

JARDIEL: ¿Ésta?... ¡Que se muera la muy zorra! (Escupe a REMEDIOS y sale corriendo.) Lo mismo se le jode el negocio, ¿no, Doña María...?

TOPETE: ¡Llame a Cipriano! ¡Hay que llevarla a...!

(TOPETE ayuda a REMEDIOS a levantarse.)

TOPETE: Venga Remedios, vamos... ¡Cipriano, Cipriano!

REMEDIOS: (Gritando.) ¡No deje que me la maten, no deje que me la quiten...! ¡Por favor! (Grita de dolor.);Me lo ha prometido, no deje que me la quiten...! 
(Salen TOPETE y REMEDIOS.)

TOPETE: (Desde fuera.) Venga Cipriano, llévela a la enfermería, ¡de inmediato! ¡Venga, venga!... ¡ Vamos!

(CARMEN está acurrucando al trapo. Entra TOPETE de nuevo en la celda.)

TOPETE: Venga, Carmen, vamos... que te llevo a la otra celda, con las otras... ¡Venga!

(CARMEN se saca los pechos y se los acaricia lascivamente mirando a los ojos a la directora. TOPETE saca una pequeña fusta y empieza a golpearla mientras CARMEN sonríe.)

TOPETE: Te voy a quitar yo esa sonrisa de la cara...

(Sigue golpeándola hasta que CARMEN deja de sonreír.)

\section{Escena X}

\section{(En el despacho. ANTONIO habla por teléfono.)}

ANTONIO: Sí... bueno, ya sabes cómo es, siempre ha sido muy cabezón. Pero tiene que salir, sí... ya sé que la muerte de un hijo nunca se supera pero... no, que no... que, claro que me hago cargo... Jardiel está bien, es un buen chico, y está eligiendo bien... ya, esas cosas son propias de los jóvenes que prueban. Está completamente entregado con la Nueva España, y le estoy recomendando para que haga carrera. Sí... una mujer, no sé... la conoció hace unos días... ya, ya le he dicho que venga a cenar con ella... sí, no hay nada como atar en corto y poner las cosas claras... con los hijos siempre es así. No llores que no ha sido más que un accidente, además se lo ha cosido el mejor cirujano de Madrid, ha quedado perfecta, por suerte el trocito de oreja no se desprendió del todo... Sí, tranquila... En unos días... me encantaría ir para allá pero tengo muchas cosas que... sí, sé que le alegraría pero... bueno... Pilar, no, no creo que sea buena idea vernos solos, ya sabes lo que pasó la última vez, el pasado es pasado y a nadie... yo le trato como a un hijo, eso te lo debo, pero... sí, sí... yo también me acuerdo... ¿ Tú crees que él sospecha algo?, no hace más que decirme que... ¡Cómo le voy a decir eso!... Yo soy un... Pero él lo sabe... (Entra Don ADOLFO y Don ANTONIO le indica que se siente.) Bueno, sí... te tengo que dejar... sí, adiós, Doña Pilar... (Cuelga.)

ADOLFO: Lo siento, Don Antonio... He venido en cuanto me han avisado... 
ANTONIO: Sí, buenas noticias Don Adolfo... ya me he enterado... un parto difícil. Pero cálmese, Don Adolfo, cálmese.

ADOLFO: Le juro que lo intento pero... es que es ella no quiere niñas, quiere darme un hijo, está como obsesionada... No sé cómo se lo va a tomar, estoy temiendo la hora de decírselo.

ANTONIO: Bueno, mírelo por otro lado, por uno positivo... Está completamente sana, de verdad se lo digo. Mire, dentro de unos meses, un año quizá, recoge usted a un varón, yo mismo le puedo facilitar los papeles. Tampoco tiene por qué llevarse a esta niña si no quiere, seguro que en el Auxilio Social o...

AdOLFO: Si yo me la llevaría pero... es mi mujer, que ahora tiene todo comprado... azul... pero está todo en casa... el carrito, los pijamas, no sé, todas esas cosas de bebés. Dice que le da igual que sea niña pero...

ANTONIO: Bueno, quizá sea verdad, ya verá... las mujeres se apaciguan cuando se realizan en la maternidad. Ya verá usted el cambio.

ADOLFO: Ojalá tenga usted razón... Ojalá... ¿ ¿La puedo ver?

ANTONIO: Sí, como no, ande... vaya a ver a la Directora, a Doña María. Ya verá que risueña es... y rubia, muy rubia. Parece alemana.

(Se levantan. ANTONIO le acompaña hacia la puerta.)

ADOLFO: Hay otra cosa, que me anda... No me vaya usted a interpretar mal, pero es que ya sabe... Bueno... ese Jardiel, ¿es de toda su confianza?

ANTONIO: Como un hijo, ¿ipor qué? ¿Le ha importunado? ¿Está descontento?

ADOLFO: No, no... al contrario, es todo un caballero. Yo tuve la suerte de estudiar con su padre...

ANTONIO: Gran amigo mío.

ADOLFO: Olvídelo... es que, tengo algunos amigos que me han contado unas historias... ni se imagina...

ANTONIO: La juventud, divino tesoro... Todos tenemos pequeños tropiezos, pequeñas cositas sin importancia... ¿ ¿usted no?

ADOLFO: Sí, claro, imagino.

ANTONIO: Dígale a sus amigos que hay conversaciones que les pueden quedar grandes. Madrid es como un corral de comedias, nunca sabes quién sabe qué cosas, ninguno estamos libres, ¿iverdad, Don Adolfo? ¿Usted lo está?

ADOLFO: No, claro... Se lo diré, Don Antonio, se lo diré...

ANTONIO: Usted preocúpese de lo nuestro, de la empresa que vamos a llevar a cabo. Quizá podría usted regentar uno de los puestos de poder en esa nueva Inquisición, 
¿quién sabe?... Si nuestro Caudillo accede... Ahora ocúpese de su hijita... ¿ ¿cómo la va a llamar?

Adolfo: No sé, eso es cosa de mi mujer... creo que como su madre, Inmaculada Concepción. Pero no lo veo claro, no lo veo claro, de verdad...

ANTONIO: Nombre cristiano y muy adecuado, sí señor. Bueno, ahora si me permite debo terminar unos asuntos de extrema importancia.

ADOLFO: Sí, sí, cómo no. Le pido perdón, Don Antonio... ya me voy (Va a salir.)

ANTONIO: Por cierto, Don Adolfo, si no es indiscreción, ¿quiénes son esos amigos suyos?

ADOLFO: ¡Ah!, no son amigos... gente, gente malpensada y que le gusta demasiado el alcohol, ya sabe, este Madrid...

ANTONIO: Ya... bueno, lo dicho... Cada uno a lo suyo y así ninguno nos metemos en cosas... digamos... incómodas para todos.

\section{Escena XI}

(CARMEN está en la celda, balanceándose. Parece encontrarse mejor. Ha dejado el trapo a un lado y lo mira. TOPETE entra con REMEDIOS que está débil, como drogada.)

TOPETE:...y descansa, que te vendrá bien para el pecho...

REMEDIOS: $\mathrm{Y}$, ¿ mi niña?... ¿ ¿dónde está mi niña?

TOPETE: Ya te lo he dicho, que Dios la tenga en su gloria, la pobre, tan pequeñita...

REMEDIOS: Pero yo la oí llorar...

TOPETE: Carmen, hija, a ver si puedes hacer algo por ella. Ponla unos trapos húmedos, le he dicho a las monjitas que os traigan un cubo de agua caliente.

REMEDIOS: No se vaya Doña María, que mi niña no está muerta... la oí llorar cuando se la llevaban.

TOPETE: Anda, deja de... Carmen, ahora le das las friegas, que está delirando.

(TOPETE sale.)

(CARMEN observa un rato a REMEDIOS y le acerca el trapo que siempre acurruca. REMEDIOS no quiere cogerlo, pero cuando CARMEN se lo vuelve a ofrecer lo agarra y lo acurruca.) 
CARMEN: ¿Era niña entonces?

REMEDIOS: Sí, niña... lloraba con mucha fuerza... la iba a llamar Carmen, como tú.

CARMEN: ¿ $\mathrm{C}$ Era fuerte?

REMEDIOS: No está muerta, Carmen, la he visto...

\section{(Entra TOPETE con un vaso y unas pastillas.)}

REMEDIOS: (A TOPETE.);Eres una zorra!

TOPETE: Toma anda, Remedios... ¡Déjate de tonterías!... ¡Tómate esta pastilla y mañana lo verás todo más claro! (REMEDIOS se toma la pastilla.) Y reza, hija, reza... para que su alma pase pronto del purgatorio.

CARMEN: c$^{A}$ qué hora es la cena?... me han dicho que hoy hay pescado, a mí me gusta el pescado... me recuerda a mi madre. Mi madre hacía pescado siempre. Siempre olía todo a pescado.

REMEDIOS: Me habéis robado a mi niña, me habéis robado a mi niña...

TOPETE: No digas tonterías, ¿quién iba a querer la hija de una roja? Anda (a CARMEN.) Cálmala con una de tus canciones, a ver si le hace efecto la pastilla (Le mete en la boca la pastilla a REMEDIOS.)

(TOPETE sale.)

CARMEN: Remedios... itú sabes a qué hora es la cena?

REMEDIOS: ¡Despierta, joder! ¡Carmen! (La intenta zarandear pero no puede por la debilidad y por los efectos de la pastilla. Llora.)

CARMEN: Yo estoy despierta... ¿ iy tú?

REMEDIOS: No me dejes sola, Carmen, y déjame acurrucar al trapo... sólo quiero morirme, sólo quiero morirme...

(REMEDIOS se tumba abrazada al trapo y CARMEN sigue caminando por la habitación canturreando y mirando por el ventanuco.) 


\section{Escena XII}

(Despacho.)

TOPETE: Martín, hemos hecho todo lo posible pero...

MARTín: Quizá haya sido lo mejor para ella...

TOPETE: Ahora en un rato le vamos a dejar ver a su mujer. Por cierto, le da recuerdos a su primo y le da las gracias por las atenciones.

MARTín: ¿ ¿Y quién se ocupa del entierro?

TOPETE: No se preocupe por eso, nosotros corremos con todos los gastos. Le pasaremos solo el importe del ataúd, pero como es pequeño no será mucho...

MARTín: Usen el más barato.

TOPETE: ¿Quiere usted ver el cuerpo?

MARTín: Hombre, si no le importa, yo prefiero no verla, que esas cosas siempre me han dado impresión... ¿ ¿y de Remedios, se sabe algo? ¿del indulto digo?

TOPETE: Yo no sé nada de política, Martín, en esas cosas no me meto, aunque después de parir estas cosas van rápido (Se levanta.) Sé que no es horario de visita, pero dadas las circunstancias, por eso le he llamado, para que luego su primo no diga que no sé corresponder a los favores.

MARTín: Sí, sí, gracias Señora Directora, muchas gracias. 
(TOPETE sale. MARTÍN espera. Al cabo entra REMEDIOS, enferma y dolorida. MARTÍN la ayuda a sentarse.)

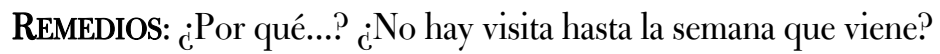

MARTín: Me han dejado verte por lo de la niña...

REMEDIOS: ¿Te han dejado verla?

MARTÍN: Sí.

REMEDIOS: No está muerta, Martín, yo la oí llorar y vi cómo se la llevaban.

MARTín: Déjalo estar, que no estás bien.

REMEDIOS: Pero, ¿ila has visto?

MARTín: Que sí, que la he visto. Y está muerta la pobre... muerta, daba impresión así tan pequeña.

(REMEDIOS llora.)

REMEDIOS: Yo no tengo la culpa de que se haya muerto Martín, dime que yo no tengo la culpa...

MARTín: (Intenta calmarla.) No la tienes, las cosas vienen como vienen...

REMEDIOS: Abrázame Martín, eres tan bueno, tú nunca preguntas... he tenido un sueño, esta noche, de cuando niña. Mi madre me ponía unas flores en el pelo para la feria, yo me sentía guapa vestida de blanco, solo tenía ese vestido y lo cuidaba como si fuera oro. He soñado eso, en el mar... i tú crees que volveré a ver el mar?

MARTín: Sí, algún día...iremos todos. Libertad ha tenido que cambiarse el nombre, la hemos puesto como tu hermana: Mari Cruz.

REMEDIOS: Nunca te pregunto por ella, por mi niña, ¿está bien?... No le digas quién es su madre, que no quiero que me vea.

MARTín: Sí, tu hermana la cuida muy bien.

REMEDIOS: Solo sé traer niñas muertas o tontas... Si algo me pasara tienes que casarte con mi hermana, ella es buena. No hace falta que me lo digas, ya sé que hace tiempo que venís... (Le hace un gesto para que no hable.) Está bien así, Martín... las cosas no duran, aquí no duran mucho, las palabras, ya sabes que no sé mucho de hablar... pero, esto que están haciendo... yo pudro todo lo que toco, todo...

\section{(Entra TOPETE.)}

TOPETE: Bueno, Remedios, que estás muy débil. Venga Martín, váyase para casa y descanse también usted... y le acompaño en el sentimiento. 
Rubén Buren

(Salen.)

\section{Escena XIII}

(En la celda de nuevo. CARMEN mece el trapo. Amanece y se escuchan los primeros cantos de pajarillos sobre el alféizar del ventanuco.)

CARMEN: Ya está amaneciendo. ¿Vamos a dar un paseo por los cerezos?

REMEDIOS: Me dijo la Topete que esté preparada, que hoy a lo mejor me llegaba el indulto, como ya he parido...

CARMEN: ¿Tú crees que hoy darán pescado?... llevan días dando pescado, odio el olor a pescado (Se frota compulsivamente.) Luego no se quita, se queda impregnado en la ropa y no sale.

REMEDIOS: Carmen... tienes que reaccionar, mira yo... en unos días ya voy a estar mejor. Tenemos que salir de aquí con fuerza.

CARMEN: Yo no quiero salir de aquí.

REMEDIOS: Claro que quieres... todas queremos... seguro que encuentras a alguien, todavía debe quedar alguien de tu familia.

CARMEN: (Sigue frotándose.) ¿Ves?... no sale, se queda impregnado.

(REMEDIOS se levanta e intenta asomarse por el ventanuco pero no llega, está nerviosa y prepara un hatillo con sus pocas pertenencias: un camisón, unas cartas.) 
CARMEN: (Al trapo.) Tú tranquilo, que yo nunca te voy a dar pescado, nunca, tú no vas a oler a mierda, ni a muerto... ¿ ¿a qué huele?

REMEDIOS: (Saca una cosita que tiene envuelta.) A azahar...

CARmen: El Azahar... (Canta.)

De hierbabuena y verde

de tomillo y azahar

de lo que mece en tu vientre

a la orillita

a la orillita del mar...

REMEDIOS: Es una pena que se pierdan todas esas canciones.

CARMEN: Me las cantaba mi madre.

REMEDIOS: ¿La del pescado?

CARMEN: (Sigue cantando y meciendo el trapo)

$\mathrm{Y}$ encontraré en tus besos

aquello que dejamos traspasar

entre nuestras manos

como una corriente

como el agua rota del mar...

REMEDIOS: Mi madre no me dejaba cantar, siempre decía que eso de gente de mal vivir... para acabar así, como estamos... mejor hubiera sido cantar... por lo menos...

\section{(Entra TOPETE.)}

TOPETE: Hijas, buenos días nos dé Dios... ¿Cómo estamos, más calmadas?

REMEDIOS: Vamos mejor... ¿qué? ¿Se sabe algo?

TOPETE: Sí, hija mía, ya ha llegado lo tuyo. Te van a trasladar a la normal y en breve ya verás que llegará lo tuyo, que no todo van a ser penas. Ya verás como al final todo esto es labor de Dios, que te está haciendo pagar por tus pecados. Pero seguro que en unos días sales de permiso. Prepárate que ahora vengo a por ti.

REMEDIOS: Gracias, Doña María... sé que usted no me tiene simpatía pero... (Piensa unos instantes, se acerca y besa la mano de TOPETE.)

TOPETE: Así me gusta, hija mía, que encuentres el camino. Mira, vamos las tres a rezar tres Avemarías por nuestros pecados.

(TOPETE comienza a rezar y REMEDIOS se arrodilla sin decir nada. CARMEN sigue canturreando en voz baja.) 
TOPETE: Bueno, muy bien, así me gusta Remedios, que seas piadosa... no vaya a perderse tu alma. Y he rezado también por tu hijita, para que esté bien y pronto vaya al cielo. Que salga pronto del purgatorio.

REMEDIOS: Gracias madre.

(TOPETE sale.)

REMEDIOs: Lo ves, salgo, yo rezo y lo que haga falta... ¡esa zorra!, se piensa que... Carmen, Carmen... yo no me voy a olvidar de ti, cuando esté en la calle voy a contar todo lo que pasa aquí. Todo. El loquero ha cumplido, que me sacan, ya verás... Y te voy a enviar paquetes de comida.

CARMEN: ¿Carne?

REMEDIOS: Sí, carne, mucha carne, montones de carne... en cuanto encuentre algo... ya verás qué pronto te puedo sacar de aquí.

(Se abrazan y REMEDIOS llora emocionada.)

REMEDIOS: Tú eres mi hermana, Carmen, que hemos pasado mucho juntas... yo te voy a sacar de aquí... (Le da una ramita de azahar envuelta.)

(Entra TOPETE.)

TOPETE: Venga, hija, vamos que ya es la hora.

REMEDIOS: Voy, Doña María.

(REMEDIOS da un beso en la frente a CARMEN y sale con TOPETE. CARMEN se levanta e intenta mirar por el ventanuco.)

CARMEN: (Al trapo.) Todavía es de noche, mi niño duerme, mi niño duerme...

(Se escucha la voz de REMEDIOS desde fuera, apenas se entiende. Grita.)

REMEDIOS: (Desde fuera.) ¡Hijos de puta! ¡Es usted una zorra! ¡No podéis hacerme esto! ¡Cabrones! (Llora y grita. Le dan un golpe y calla.)

CARMEN: (Comienza a cantar y se tapa los oídos, nerviosa.)

Soledad, de verte sola 
Soledad, de estar a tu lado

sin poderte tocar.

Sin que nadie nos dé nombre,

a la orillita del mar

(Fuera suena una ráfaga de fusiles y poco después un disparo de pistola. CARMEN se detiene unos instantes, intenta cantar pero no puede. Llora. Al cabo, acurruca el trapo e intenta seguir cantando.)

Soledad, del mar rompiendo

Soledad, con olor a hierbabuena y sal

De lo que se llevó el viento

a la orillita del mar

Quizá por eso sigo en pie,

Quizá las horas

no sean más que palabras

Quizá el rumbo lo encontré

Y se me perdió

En la orillita,

a la orillita del mar.

(Desenvuelve la ramita de azahar y lo huele. Piensa y lo envuelve dentro del trapo.)

De hierbabuena y verde

de amarillo y azahar

de lo que mece tu vientre

En la orillita

A la orillita del mar.

Fin

(Día Miércoles 7 de Marzo de 2012) 


\title{
LA SONRISA DEL CAUDILLO. VALLEJO-NÁGERA Y EL ROBO DE NIÑOS. DE LA REALIDAD A LA FICCIÓN
}

\author{
Rubén Buren
}

\section{Introducción}

El comienzo del robo de niños en las cárceles franquistas se debió a la conjunción de varios factores. En primer lugar, la deshumanización del enemigo, por parte de los psiquiatras franquistas, tomando como base las teorías eugenésicas importadas de Alemania, EE.UU, y mezcladas con el Nacional Catolicismo, que conceptualizaban la ambientalidad marxista como un factor para la activación genética del "gen rojo". Por otro lado, la relegación de los derechos de la mujer hasta ser un ciudadano de segunda clase. Para que la labor fuera efectiva hubo de contar con la unión del Estado, las instituciones penitenciarias y las organizaciones médicas y de la Iglesia.

Según las tesis de psiquiatras como el Doctor Vallejo-Nágera, la extracción de niños de familias con tendencias democráticas o marxistas y su inclusión en otras unidades familiares de demostrada querencia católica y española, podría revertir el posible desarrollo genético del mal. Al fin y cabo, lo que interesaba en una España maltrecha y aislada, era el aumento de la natalidad, no la calidad de la misma. Había que promover la natalidad para el proceso de autarquía propuesto por el gobierno de Franco, es decir, la autogestión del país en todos sus ámbitos, sin extranjeros que volvieran a contaminar con sus ideas y costumbres el espíritu nacional y su cruzada divina. Y el hecho de ser español de cuna, hijo de españoles, ya era suficiente distintivo para ser especial en la nueva Hispanidad que se estaba creando. Eso sí, cada uno en su nicho social, prefijado por Dios. Antonio Polo Blanco en sus conclusiones sobre el Gobierno de las poblaciones en el primer franquismo (1939-1945) nos los resume:

El exterminio del enemigo republicano centró las prácticas de gobierno con la intención de eliminar del conjunto de la población nacional la enfermedad del republicanismo. Del resultado de esta eliminación habría de forjarse una nueva "etnia" de españoles redimidos eugenésicamente de la mácula republicana. La abundancia en los nacimientos habría de, además de contentar a la moral de la Iglesia, conseguir sacar del letargo infecundo al pueblo español. De esta forma, se contribuiría a colocar a la nación española al frente de las naciones selectas (Polo, 2006: 237-238). 
Siempre con la obsesión de sacar a España de ese rincón de la historia en el que, por los conatos liberales y obreros, según los conservadores había quedado relegada desde hacía años.

El objetivo de nuestro artículo es adentrarnos en los sucesos históricos que rodearon el robo de niños en las cárceles franquistas y contrastarlo con la recepción estética que realizan los dramaturgos en el siglo XXI. Cómo se trasvasan los hechos y personajes reales en la construcción de una ficción dramática, ya sea en el ámbito teatral o cinematográfico. De qué medios se valen y cuál es su función memorialista.

El presente trabajo se dividirá en los siguientes puntos:

1. Abordará el problema de la masificación de las cárceles después de finalizada la contienda civil.

2. Examinaremos las teorías psiquiátricas de Vallejo-Nágera en referencia a la criminalización del marxismo y a sus teorías misóginas.

3. Analizaremos la posición nueva que adquiere la mujer en el Nuevo Régimen y la maternidad en las cárceles franquistas.

4. Buscaremos los antecedentes ficcionales sobre el robo de niños.

5. Analizaremos el proceso de creación del mundo ficcional de la obra teatral La sonrisa del Caudillo de Rubén Buren, a través de la investigación histórica.

\section{El problema de las cárceles}

El 10 de noviembre de 1936, el sevillano Melchor Rodríguez, anarquista, es nombrado a regañadientes por el nuevo Ministro de Justicia de la República, el cenetista Juan García Oliver, que no simpatiza mucho con los andaluces, Delegado Especial de Prisiones, con funciones de Director General. De esa manera se pone un punto y aparte a las matanzas indiscriminadas en las cárceles de Madrid y Guadalajara, incluidos los pueblos adláteres de la capital. A manos del pueblo, las milicias o grupos indiscriminados de una $\mathrm{u}$ otra sigla, era frecuente en la España fiel al gobierno legítimo de la República entrar en las dependencias carcelarias después de un bombardeo, o por el simple hecho de "pasear" por venganza. Tanto el Cuerpo Diplomático Internacional, el Cuerpo Judicial republicano, como los partidarios de la ética en la retaguardia, celebraron las acciones humanitarias de Melchor Rodríguez en favor de los presos del bando contrario. Así las cárceles madrileñas pasan a ser un lugar seguro, incluso reponiendo en sus puestos a los funcionarios de prisiones, sustituyendo así a los milicianos que se habían hecho cargo desde el 19 de julio del 36. Intentos como éstos, que en el bando afín al gobierno republicano se dan con relativa frecuencia, contrastan con la política del bando contrario. Por supuesto que la represión de las checas, cárceles bajo cuerda, y los secuestros nocturnos siguen a la orden del día en el bando de izquierdas. Pero el Gobierno Central, y buena parte de los sindicatos 


\section{Rubén Buren}

y organizaciones obreras, tratan como pueden de domeñar los ánimos. Sin embargo, la política de retaguardia de los golpistas no es más que la herencia de las costumbres militares mantenidas en el Riff, o las heredadas de las guerras coloniales, a la sazón: matanzas indiscriminadas en su avance, quema de pueblos o terror para generar miedo en el adversario. El General Yagüe, el llamado "carnicero de Badajoz", llega a comentar a un periodista del New York Herald:

Por supuesto que los matamos. ¿Qué esperaba usted? ¿Que iba a llevar 4000 prisioneros rojos conmigo, teniendo mi columna que avanzar contrarreloj? ${ }_{\mathrm{c}} \mathrm{O}$ iba a soltarlos en la retaguardia y dejar que Badajoz fuera roja otra vez? (Southworth, 1963: 123).

Con ésta política de aniquilación, a los privilegiados que no morían en carreteras y campos, y llegaban a prisión, no les esperaba una estancia larga sino una corta espera de torturas antes del juicio sumarísimo que los llevase al paredón. Como afirma Paul Preston en su libro El Holocausto Español, tal fue la brutalidad ejercida en la represión que muchos de los represores quedaron marcados para el resto de sus vidas y murieron arrepentidos o alcohólicos, o incluso siendo perseguidos por los fantasmas de los represaliados. Pero en aquellos momentos era un deber divino limpiar España de las almas impuras que habían abrazado las políticas de izquierdas que tanto mal habían hecho a la Fe y a la Raza. Dentro de éstas víctimas silenciosas las hay de dos tipos: mujeres y hombres. A los hombres se los tortura y se los fusila; a las mujeres se las viola, se las tortura y se las fusila.

La guerra termina y con ella se llenan las cárceles, los hospitales, los conventos y cualquier edificio que pueda ser utilizado para el hacinamiento de "rojos" en espera de juicio. La rendición de Madrid con el golpe de Casado o la bolsa de Alicante y Valencia, republicanos que buscan inútilmente salir en barco del país, rellena unas cárceles ya colapsadas. El delito de rebelión contra el Gobierno de Franco se hizo retroactivo, la "justicia al revés" como la calificaría en sus memorias el "cuñadísimo" Serrano Suñer, y se convirtió en una verdadera locura logística. En investigaciones como la de González Duro establecen una población de unos 280.000 presos en 1940 (González Duro, 2008: 235). Tal fue así que obligó al gobierno de Franco a realizar indultos cada vez más frecuentes para descongestionar las cárceles. Hasta que con el Decreto del 9 de octubre de 1945 se concede el indulto total a los condenados por delito de "rebelión militar y otros cometidos hasta el $1^{\circ}$ de abril de 1939" (BOE, 1945). Una política que había comenzado en 1940 ante la masificación carcelaria. Indulto que vino acompañado de una serie de disposiciones, 
comentarios y artículos como la distinción entre los condenados que fueron arrastrados por una equivocada pasión política y los que dirigieron, y excitaron, a las masas al crimen ${ }^{1}$.

La población carcelaria queda dividida en dos: los anteriores al $1^{\circ}$ de abril y los posteriores al triunfo del ejército sublevado. Es importante entender que hay dos tipos de delito: los que se cometen por la exaltación de la contienda, que de algún modo tienen una excusa por la excitación general o la alienación marxista; y los ataques directos contra el orden ya establecido de la dictadura franquista posteriores a la victoria. Estos últimos ataques corresponden a elementos politizados que no tienen posibilidad de reforma ni depuración social. Y son: la lucha de los guerrilleros (también llamada "el maquis" en algunas zonas de la península por influencia de la resistencia francesa contra los nazis); los exiliados políticos en activo, que actúan en el interior de la península; o los que, fuera de España o dentro, todavía militan en organizaciones "antiespañolas". Después del triunfo golpista, todos estos elementos carecen de cualquier derecho y son utilizados como carne de cañón. Durante los tres años de contienda no es ningún seguro de vida estar encarcelado en el bando fascista: el hacinamiento, el hambre y las torturas son el plato de cada día, después de esa fecha, "a pesar de la realidad de los indultos, las excarcelaciones y la libertad condicional, el problema penitenciario también se aligeró por la ejecución firme de las condenas y la propia morbilidad de una población reclusa sometida a aquellas condiciones" (Gómez Bravo, 2006: 9-10).

\title{
3. Las teorías de Vallejo-Nágera
}

Sin duda, para un psiquiatra de la talla de Antonio Vallejo-Nágera, la población reclusa, voluntaria forzosa de sus experimentos filonazis, era un campo inmenso de investigación donde contrastar sus teorías. La búsqueda del "Gen Rojo", es una consecuencia de sus teorías genetistas, como las expresadas en sus artículos y libros como Eugamia, sobre la selección de novios:

\begin{abstract}
Actualmente, la mezcla de clases impide se tenga en cuenta la alcurnia, concediéndose importancia a la posición económica, sin importar cómo se haya adquirido la riqueza, o cómo se gana el pretendiente la vida, si por medios lícitos o ilícitos, morales o inmorales. Asombra que la ciencia moderna haya dado la razón a nuestros abuelos cuando pesaban y medían las gotas de sangre azul en la ascendencia del candidato a novio para que los matrimonios no resultasen desiguales. Siguiendo en esta conducta una de las normas de la moderna política racial, aunque la pureza de estirpe se interprete hoy en el aspecto bioantropológico, no en el aristocrático (Vallejo-Nágera, 1938c: 104).
\end{abstract}

\footnotetext{
${ }^{1}$ Casualmente, como dato curioso, el indulto vino firmado por el Ministro de Justicia, el falangista Raimundo Fernández Cuesta, salvado de la represión republicana por Melchor Rodríguez.
} 
Pero Vallejo-Nágera se desvía ligeramente del camino de sus admirados científicos alemanes ya que, en lugar de la aniquilación total, él defiende, más cristianamente, la redención genética por la fe y el ambiente católico. El peso de las "fuerzas ambientales" puede contrarrestar una mala predisposición genética. De ahí que se opte por la adopción de niños de madres marxistas a familias "puras" y no por su condena a muerte. La veda para el negocio de la venta de niños, inevitablemente, quedará abierta.

Antonio Vallejo-Nágera (1889-1960), estudió medicina en la Universidad de Valladolid y entró en el Cuerpo de Sanidad del Ejército en 1910. Después de ser agregado militar español en la embajada de Berlín, en la Gran Guerra vuelve para trabajar en la Clínica Psiquiátrica Militar de Ciempozuelos y luego a ocupar su plaza de profesor de Psiquiatría en la Academia de Sanidad Militar desde 1931. Más que racista, Vallejo creía en una mejora gradual de la sociedad en favor de los más "aptos" y la selección de novios para engendrar nuevas criaturas, gradualmente más puras. Así, después de muchas investigaciones con soldados sobre la psicosis de guerra durante el conflicto y de muchas peticiones al Generalísimo, éste le contesta:
En contestación a su escrito del 10 del actual proponiendo la creación de un Gabinete de Investigaciones Psicológicas cuya finalidad primordial será investigar las raíces psicofisicas del marxismo, manifiesto que de conformidad con su mencionada propuesta, autorizo la creación del mismo. Francisco Franco. Telegrama n ${ }^{\circ} 1565,23$ de agosto 1938. Entregado en la Inspección de Campos. (Vinyes, 2010: 50-51)

Resulta inevitable apuntar la relación de Vallejo con sus camaradas alemanes en las similitudes de los estudios con Brigadistas Internacionales en San Pedro de Cardeña (Burgos), que algunos supervivientes compararon con el Campo de Dachau, años después, y el Instituto para la Investigación y Estudio de la Herencia creado por Himmler en Mecklenburg. El gabinete concluyó su estudio en octubre de 1939 con felicitaciones del Estado Mayor del Ejército. También los brigadistas norteamericanos hablan de agentes de la Gestapo, policía secreta nazi, y científicos alemanes que tomaban mediciones antropométricas e interrogaban a los prisioneros. Vallejo explicaría en su artículo Biopsiquismo del Fanatismo Marxista que las investigaciones del Gabinete tenían el objetivo de relacionar las cualidades biopsíquicas del sujeto y el fanatismo políticodemocrático-comunista:

El simplismo del ideario marxista y la igualdad social que propugna favorecen su asimilación por los inferiores mentales y delincuentes culturales, incapaces de ideales espirituales, que hallan en los bienes materiales que ofrecen el comunismo y la democracia la satisfacción de sus apetencias animales. El inferior mental y el inculto encuentran en la política marxista medios que en cualquier 
otro régimen político-social, especialmente en los aristárquicos que fomentan el encumbramiento de los mejores, no lo haría (Vallejo-Nágera, 1938: 172).

La división se hace en cuatro grupos: los presos brigadistas internacionales; los presos políticos varones, agentes y propagandistas del marxismo; los presos políticos hembras; y los marxistas catalanistas, en los que se unía el fanatismo marxista y el sentimiento antiespañol. En el caso que nos ocupa, el de las mujeres presas, se publicó en mayo de 1939 la continuación del Biopsiquismo con el subtítulo de Investigaciones psicológicas en marxistas femeninos delincuentes, teniendo Vallejo la inestimable ayuda del teniente Eduardo Martínez, director de la Clínica Psiquiátrica de Málaga y jefe de los Servicios Sanitarios de la Prisión Provincial de la misma ciudad.

Recuérdese, para comprender la activísima participación del sexo femenino en la revolución marxista, su característica labilidad psíquica, la debilidad del equilibrio mental, la menor resistencia a las influencias ambientales, la inseguridad del control sobre la personalidad y la tendencia a la impulsividad, cualidades psicológicas que en circunstancias normales acarrean anormalidades en la conducta social y sumen al individuo en estados psicopatológicos. Si la mujer es habitualmente de carácter apacible, dulce y bondadoso débese a los frenos que obran sobre ella; pero como el psiquismo femenino tiene muchos puntos de contacto con el infantil y el animal, cuando desaparecen los frenos que contienen socialmente a la mujer y se liberan las inhibiciones frenatrices de las impulsiones instintivas, entonces despiértase en el sexo femenino el instinto de crueldad y rebasa todas las posibilidades imaginadas, precisamente por fallarle las inhibiciones inteligentes y lógicas (Vallejo-Nágera \& Martínez, 1939: 398).

Todos estos estudios están repletos de cifras, nombres técnicos, y continuas referencias a contrastados estudios y tesis como las de Neymann-Kohlstedt, Marston-Mira, Binet-Simon o el método Yerkes. Realmente ese revestimiento técnico era necesario si querían argumentar científicamente la tesis de que habían ganado la batalla los más aptos y de que el pensamiento de izquierdas, sin fe ni principios morales, debía ser extirpado de cualquier sociedad que no quisiera estar enferma. A ojos neófitos puede resultar un trabajo riguroso, pero la crítica a esos estudios, desde un punto de vista profesional es muy sencilla: "falta de condiciones ambientales en las que las respuestas de los sujetos pudieran tener un mínimo de credibilidad, ausencia de una descripción detallada del procedimiento (...) y falta de rigor en el uso de la terminología biopsicológica" (Bandrés \& Llavona, 1996: 9).

\section{El papel de la mujer en el Nuevo Régimen}

Para desmantelar las pocas libertades conseguidas por la mujer desde el siglo XIX era necesario un planteamiento científico de primer orden, no bastaba con la prohibición o 


\section{Rubén Buren}

la opinión, y para ello había que poner en marcha una maquinaria ideológica encabezada por los más destacados pensadores y psiquiatras. La mujer debía ser una pieza fundamental de las nuevas estructuras pero, para ello, debía olvidar (o convencerse) de las perniciosas semillas implantadas por las escuelas ferrerianas, los ateneos libertarios o las Casas de Cultura de los partidos y organizaciones de izquierdas, que habían introducido las ideas emancipadoras del hombre y la mujer desde el siglo XIX, anteriores a la Cruzada Española de 1936. Desde ahora los obreros volverían a su lugar, la obediencia, y la mujer al suyo, la maternidad.

La despoblación provocada por la guerra Civil y las duras condiciones sanitarias de la posguerra española provocaron una considerable disminución de la natalidad. También la más o menos incipiente incorporación de la mujer al trabajo en la II República, con sus pequeñas cuotas de libertad conquistadas para el género femenino en diferentes ámbitos, fueron cercenadas de raíz con el Nacional Catolicismo (O Nacional Sindicalismo) interpretado por el Nuevo Orden franquista. El culto nazi a la juventud, tan ampliamente citado en revistas y cine alemán fue desembarcando, al igual que investigadores, psicólogos y médicos, hacia la Nueva España, trayendo consigo una infinidad de tesis que llevaban años discutiéndose en todo el mundo. El Volk ohne Jungend² (pueblo sin Juventud) debía ser un principio para la reconstrucción del Imperio.

La biología femenina, predispuesta, según el Doctor Vallejo-Nágera, a la psicosis y a los factores patógenos, no ayudaba a su incorporación al mundo laboral y sus puertas quedaron de ese modo cerradas a la mujer. Con esto, por un lado se las relegaba a las labores domésticas del hogar, con un conjunto de deberes bien reglados por la Sección Femenina comandada por la inmaculada Pilar Primo de Rivera, desde 1934. La hija del exdictador parafraseaba, en muchas de sus charlas a mujeres, un extracto de un discurso de 1935 de su hermano José Antonio, fundador de la Falange:

A mí siempre me ha dado tristeza ver a la mujer en ejercicios de hombre, toda afanada y desquiciada en una rivalidad donde lleva - entre morbosa complacencia de los competidores masculinos - todas las de perder. El verdadero feminismo no debiera consistir en querer para las mujeres las funciones que hoy se estiman superiores, sino en rodear cada vez de mayor dignidad humana y social a las funciones femeninas (Sánchez López, 2007: 41).

O se hacía entender la obediencia de carácter general, no solo femenina:

\footnotetext{
2 Frase de Federico el Grande recogida por el historiador fascista alemán Spengler en alguno de sus discursos en los que habla de la misión de la juventud alemana. Citamos: "Una Internacional efectiva sólo puede establecerse por el triunfo de los ideales de un pueblo sobre los demás... Arrojemos las ideologías anticuadas. No hay reconciliaciones en la historia verdadera (...) No hay sino un fin de la permanente lucha; la muerte; la extinción de un individuo, de un pueblo, de una cultura". (González Rodríguez, 1960: 129).
} 
Nosotros los subordinados, no tenemos más misión que obedecer. Debemos obedecer sin discutir. Quien manda sabe lo que hace y por qué lo hace. Los españoles tenemos la obligación de acostumbrarnos a la santa obediencia... ¿ $\mathrm{Y}$ quién juzga al que tiene el máximo poder? Dios y la Historia (Anónimo, 1944: 20-21).

Por otro lado, se favorecían la revitalización de la natalidad, premiando moralmente la maternidad como misión divina impuesta a su género. Por supuesto la Iglesia también ejerció su posición de maestro moral aplicando rigurosamente estas tesis en la escuela y el púlpito. El padre Claret en su obra Camino Recto, ampliamente difundida desde el siglo XIX, nos explica claramente en su capítulo dedicado a las obligaciones de los maridos frente a las mujeres que éstos deben: "dirigirlas como a inferiores", "sufrirlas con paciencia" o "corregirlas con benevolencia". Sin embargo, en el capítulo contrario, el de las obligaciones de la mujeres para con sus maridos, nos orienta diciendo: la mujer debe "respetarlo como a su cabeza", "obedecerlo como a superior", "ayudarlo con reverencia", "contestarle con mansedumbre", "soportar con paciencia sus defectos" o "saber callar cuando esté enojado". Sin duda, leyendo la obra de Claret, el plan propuesto anula buena parte de los conflictos familiares, a base de despojar a la mujer de toda autonomía y libertad en favor del hombre, con o sin preparación moral. "Habrá de conceptuarse el trabajo femenino como un mal tolerado y contra el que hay que luchar como se lucha contra el alcoholismo, la sífilis o la lepra" (Bosch Marín, 1943: 27).

La persecución social de la mujer que opta por trabajar queda instaurada, tachándola de asocial o psicótica y, en el caso de tener que mantener a la familia, es preferible las labores remuneradas desde el hogar: coser, zurcir, cocinar, planchar, ensobrar, etc. No solo el trabajo, las demás costumbres liberales, como todos y cada uno de los valores que no promovían la medievalización de España, eran tachados de "costumbres extranjeras" y quedaban a la altura infernal del marxismo, el anarquismo o la democracia. Se instauraba así la libertad moral al servicio de un credo patriótico y de un ideal eterno, como diría el invicto General Franco en sus discursos, es decir, la libertad moral con muchas condiciones. "A la sociedad le importan madres robustas y hembras prolíficas, mantenidas por varones vigorosos, aptos para la guerra y para la caza", afirmaba Vallejo (Vallejo-Nágera, 1943: 60). Ante estas afirmaciones, cercanas a la glorificación de estructuras sociales prehistóricas de Vallejo, tampoco había necesidad de la incorporación de la mujer a la universidad ya que no está preparada para entender los estudios por problemas de índole biológico y, mucho menos, está capacitada para desarrollar. Así se dejan en manos de los padres, de los maridos y, en última instancia, si es muy díscola, del Estado, el convencerlas de cejar en sus pretensiones intelectuales.

Así la mujer española quedó al servicio del hogar y la incultura. Las pobres hijas o mujeres de rojos, o rojas ellas, solo pudieron optar a trabajos de segunda o tercera categoría 


\section{Rubén Buren}

que apenas las permitían sobrevivir. Carmen Martín Gaite explica las penalidades por las que tuvieron que pasar las mujeres de clase baja en muchas ocasiones:

Las muchachas de servir llevan una cruz a cuestas, pues en su casa no pueden tenerlas por falta de medios y están siempre expuestas, lejos de sus padres, a caer en innumerables peligros. Los salarios, por lo general, son bajos y no les bastan para atender a sus necesidades, cosa que las obliga a veces a recurrir a medios deshonestos para hacer frente a la vida (Martín Gaite, 2002: 103).

\section{Las presas y la maternidad}

El problema que surge a continuación es: ¿y los niños que viven en las cárceles qué derechos tienen? ¿ ¿ $Y$ los niños nacidos de presas rojas dentro de las prisiones qué futuro tienen en la "Nueva España"? En el magnífico resumen que realiza Ricard Vinyes, podemos ver cómo los hijos de los presos rojos son tratados como mera mercancía sobrante que refuerza la beneficencia o las órdenes religiosas, siempre ávidas de nuevos miembros:

Tipologías de lo que sucede con los niños en el momento de su detención, en la cárcel, o con posterioridad al fusilamiento de los padres:

1) Los niños son entregados a algún vecino, que lo entrega a algún familiar o a la beneficencia. El Familiar lo entrega a menudo a la beneficencia por falta de recursos.

2) Los niños son derivados al Auxilio Social, hospicios y centros religiosos, especialmente niñas.

a) A veces con consentimiento paterno, a menudo sin él.

b) Los padres pierden la tutela legal.

c) Hijos e hijas ingresan en la orden religiosa de acogida en bastantes casos, argumentando la expiación de las culpas familiares.

d) En algunos casos desde los centros de acogida se cambian los nombres y se dan en adopción.

3) Los hijos que asisten a la detención de la madre son trasladados con ella a Comisaria y asisten al interrogatorio y tortura; en el caso de adolescentes son también torturados ante sus padres y viceversa.

4) Ingresan con la madre en la cárcel, sin que su ingreso sea registrado.

a) Mueren a causa de malos tratos, sean o no recién nacidos.

b) Mueren por el ambiente insalubre y la alimentación del presidio. 
c) $\mathrm{Al}$ cumplir cuatro años son excarcelados y trasladados a centros religiosos, o centros del Estado, a menudo sin autorización paterna. En ocasiones el traslado se realiza sin destino conocido por los padres, iniciando el camino de la beneficencia sin conocimiento familiar.

5) Son capturados por Falange Española en el exilio y trasladados a España sin consentimiento. Ingresan, en general, a la beneficencia.

6) Si están con la madre en el momento del fusilamiento son entregados, a menudo, a órdenes religiosas (Vinyes, 2010: 101).

Debemos entender que muchos de esos hijos que nacían en las cárceles eran fruto de las violaciones ocurridas dentro de prisión y que muchas de esas madres, o futuras madres, debían enfrentarse al rechazo personal de la criatura que llevaban dentro o al rechazo de sus maridos o familiares, cuando los había. Como siempre, las mujeres sufrían el peso del machismo de los dos frentes, porque no olvidemos que en las izquierdas apenas se tuvo tiempo de erradicar mínimamente el fuerte machismo arrastrado de siglos anteriores. La Orden del Ministerio de Justicia de 30 de marzo de 1940 establecía que los hijos de presos políticos podían quedarse con sus madres sólo hasta los tres años, después deberían ser excarcelados. La Ley de 4 de diciembre de 1941 facilitaba a su vez su inscripción en el Registro Civil con nuevos apellidos, incluso se dan casos de niñas que salen y entran de los conventos siendo adoptadas por varias familias sin éxito. En muchos testimonios recogidos por Tomasa Cuevas, muchas mujeres hablan de robos directos en la sala de partos. Incluso, algunas condenadas a muerte en espera de dar a luz eran fusiladas el mismo día o al día siguiente de parir. Y esos niños desaparecían misteriosamente.

\section{Antecedentes ficcionales}

En España, hasta el pormenorizado estudio de Ricard Vinyes, de principios de siglo XXI, no existe realmente una visión global del robo de niños ni del maltrato en las cárceles. Si bien en los tres libros de la militante comunista Tomasa Cuevas, con testimonios directos de las presas de Franco, se recoge un material inédito y de primera mano sobre el tema, con una veracidad potente y abrumadora, el asunto pasa casi desapercibido en unos tiempos de procesos de cambio y pactos de silencio. Después de Vinyes el conflicto de las presas se convierte en otra fuente para la narrativa, según explica la filóloga Luz C. Souto, en su estudio sobre las ficciones de los robos de niños en las dictaduras española y argentina:

La diferencia en la construcción de la narrativa argentina y la española es el reflejo de las necesidades de cada país respecto a sus leyes de memoria. En el 


\section{Rubén Buren}

caso argentino los personajes son puramente ficcionales, mientras en el caso español hay conciencia de denuncia, la ficción se construye alrededor de personajes identificables en la historia. De esta manera, el análisis literario se propone como una ida y vuelta con el estudio de los personajes reales para, de esta forma, dar sentido a la reconstrucción de un pasado necesario para la identidad (Souto, 2011: 222).

\section{Enfrentarse a la ficción}

Después de la investigación histórica, entrevistas y análisis de fuentes, deviene el proceso de concretización de las ideas para la construcción de una obra teatral o guion cinematográfico. En el proceso de construcción audiovisual de carácter histórico siempre hay que tener cuenta varios factores: el diseño de las tramas narrativas; la elección de personajes y su evolución; el porcentaje de rigurosidad histórica y cronológica; la introducción de elementos ajenos a la realidad: con un valor puramente emocional o con un peso de asentamiento histórico que apoye la convención escénica; la estética de la dramaturgia y puesta en escena; y los objetivos que se pretenden conseguir en el interno del lector/espectador, si son del estilo aristotélico clásico, es decir, conseguir la empatía y la catarsis, o son intelectuales y reflexivos, como el distanciamiento propuesto por Bertolt Brecht, o son una mezcla de los dos. En cualquiera de los casos, la elección es un proceso difícil en el que hay que tener en cuenta un factor: que el porcentaje de error suele ser muy grande. Sobre todo hay que trabajar para que el espectáculo tenga su propia identidad y no sea ni un pasatiempo sin fondo argumental, ni un ensayo académico puesto sobre las tablas. La finalidad del arte es deleitar, como dice David Mamet ${ }^{3}$.

La premisa inicial de La sonrisa del Caudillo, o el motor de la obra teatral, fue una entrevista a Juana Doña, el 5 de Marzo de 2001, que transcribe Ricard Vinyes:

A Julia Lázaro la violaron entre siete policías, y de una de las violaciones quedó
embarazada. La condenaron a muerte a los tres o cuatro meses de estar en la
cárcel. Ella ya sabe que está embarazada, lo dice, y entonces la meten en la galería
de las condenadas a muerte. Su hermana María (también interna en Ventas) se
queda con la gran contradicción de ese niño. Ese niño qué pasa: ella no sabe del
padre que ha sido, ha sido del martirio de su hermana, de las violaciones de su
hermana. Por una parte le horroriza el niño, por otra parte no le horroriza
porque es el hijo de su hermana, pero al fin puede más el horror que tiene al

\footnotetext{
${ }^{3}$ El párrafo exacto de Mamet es: "El propósito del arte no es efectuar cambios, sino deleitar. No creo que su finalidad sea ilustrarnos, ni que deba transformarnos, ni tampoco aleccionarnos". (Mamet, 2001: 45). Sin duda una tesis muy acorde con la industria norteamericana de cine de la que es un prolífico, y reconocido, guionista.
} 
niño que el amor que tiene a su hermana. $\mathrm{Y}$ entonces pues la Topete dice que no, que ese niño es para ella. Y ese niño se lo lleva la Topete (Vinyes, 2010: 88).

Para la construcción de La Sonrisa del Caudillot ${ }^{4}$ se trabajaron tres vías de investigación en improvisaciones, aparte de la premisa inicial, fueron: las investigaciones de Vallejo-Nágera desde San Pedro de Cárdeña; los testimonios de las propias presas, sobre todo de Madrid; y la persecución y demonización de la homosexualidad durante el franquismo.

El título de la pieza teatral fue sacado del título de un artículo del propio VallejoNágera titulado "La sonrisa del Caudillo" donde realiza un paralelismo entre la fealdad de los vencidos en contraste con belleza de los vencedores:

La comparación de las figuras corporales de nuestro invicto Caudillo y el llamado Presidente de la II República española, recuerda y exterioriza las respectivas psicologías. Llama la atención la circunstancia de que las masas identificadas con cada una de las citadas personalidades, exhiben reacciones psíquicas que parecen fruto de los complejos psíquicos latentes en la consciencia de ambos personajes. Las de ellos, reacciones movidas por los complejos de rencor y de resentimiento. Las nuestras, reaccionan a los complejos de religiosidad, patriotismo y responsabilidad moral (Vallejo-Nágera, 1938b: 14).

De todos los personajes que trabajaron en el taller, se eligieron los que nombramos a continuación:

-Carmen y Remedios. Dos presas (ficcionales, pero con muchos puntos entresacados de diversos personajes reales), una anarquista y otra comunista. Carmen, acaba de dar a luz un niño supuestamente muerto y tiene perdida la cabeza desde hace tiempo. La otra reclusa, Remedios, está a punto de parir y está condenada a muerte y recibe las visitas de un héroe de guerra franquista que, junto a María Topete, están gestionando la adopción. En la obra también se trabaja el tema de los problemas psicológicos derivados de las sistemáticas violaciones realizadas por la policía o carceleros, muchas veces los verdaderos padres de las criaturas. Algunas de estas mujeres, sometidas a mil vejaciones, perdían la noción de la realidad entre la desnutrición, la avitaminosis, las ejecuciones continuadas de compañeras y los abusos diarios. Además de Vinyes o Cuevas, también Mujeres Encarceladas (Hernández Holgado, 2003) aportó mucha luz sobre la vida en las cárceles.

-María Topete. Basado en el personaje real y en las investigaciones realizadas por Ana Ramírez Cañil para su novela Si a los tres años no he vuelto (Cañil, 2011) y las referencias de Enrique González Duro. El marco sitúa la acción en la Cárcel de Mujeres

\footnotetext{
${ }^{4}$ La obra fue estrenada en 2012 en el Paraninfo de la Universidad Complutense de Madrid, dentro
} del marco de investigación teatral que dirige Rubén Buren con estudiantes universitarios. 


\section{Rubén Buren}

lactantes de San Isidro en 1941, verdadero centro de acción de María Topete, directora de la cárcel y heredera, y mano ejecutora, de las ideas de Vallejo-Nágera. Múltiples testimonios del libro de Tomasa Cuevas dan construcción al personaje de la realidad a la ficción: de qué manera gestionaba el hospital, su odio a las "rojas" a causa de su reclusión durante la guerra en la cárcel de Ventas republicana. En la realidad es imposible saber si Topete y el Doctor tuvieron un estrecho contacto más que de alumna-profesor. La labor de dirección, según testimonios, fue a tenor de una política terrorífica frente a las madres y una labor de separación y extracción de niños en dicha cárcel y en la de Ventas.

-Don Adolfo. (Ficcional). Topete negociará con un viejo héroe de guerra, Don Adolfo, un camisa vieja de la falange, la adopción de un futuro recién nacido. Casado, pero que ha conseguido consumar su matrimonio con un hijo, algo necesario en el nuevo orden, por ello opta por la adopción solapada que le quite problemas y explicaciones sociales. Adolfo y Jardiel nos mostrarán ese mundo oculto de la perseguida homosexualidad durante el régimen (que merece un artículo aparte, en preparación). Como resumiría el BOE del 15 de Julio de 1954 (Franco, Modificación. Ley de Vagos y Maleantes, 1954) el Nuevo Régimen quería proteger al Estado y a sus ciudadanos de estos "sujetos caídos al más bajo nivel moral", a la sazón "los rufianes, homosexuales y proxenetas", teniendo una especial dedicación a los homosexuales que debían ser separados de los demás. Para ello establecen por escrito unas disposiciones que los relegaban a ser perseguidos, vigilados, separados y examinados médicamente. Los homosexuales hijos de aristocracia o gente de poder en la España triunfante pudieron utilizar sus contactos en las altas esferas, hasta en el papado, para organizarse o bien para librarse de penas. Los más pobres fueron fusilados o sometidos a vejaciones médicas muy cercanas a las nazis. Para los psiquiatras López Ibor, o VallejoNágera, la persecución y estudio de la homosexualidad fue realmente otro de sus campos de batalla. Gregorio Marañón llegó a escribir:

Yo he recibido en mi despacho confesiones inesperadas de gentes que jamás despertaron la menor sospecha de su instinto torcido ni aun en sus más íntimos allegados (...) No hay que decir que, en estas cuestiones, la fe y la disciplina religiosa suelen ser la razón suprema de que la conducta se haya mantenido limpia y el alma en paz. En ésta, como en todas las tempestades del espíritu, la ayuda de Dios es, claro, lo esencial (Marañón, 1951: 158).

-La figura de Antonio Vallejo-Nágera, del que ya hemos hablado en el artículo. A mitad de camino entre lo real y lo ficcional, pretende acercar sus postulados sobre la nueva manera de entender España al espectador con el adiestramiento de un nuevo pupilo, también ficcional, Jardiel.

-Jardiel, personaje de ficción. Supuesto hijo de un compañero militar de Vallejo, aprendiz de psiquiatría y homosexual. La idea de este personaje es enfrentar a Vallejo con la 
homosexualidad frente a los derechos de cuna, una de las disyuntivas de esa nueva sociedad como ya hemos tratado. También tendrá que tomar él mismo la decisión, como decía Marañón, entre suavizar sus impulsos para formar parte de la élite del Estado o seguir con su querencia innata y ser un desplazado social.

Como apuntaría el catedrático Valentín Pérez Ardiles en su discurso de apertura del curso académico, ante las tesis de la inocencia del homosexual:

La comparación sería más justa si dijera: 'Tampoco el tuberculoso es responsable de su tuberculosis; pero tendrá una grave responsabilidad cuando por odio al resto de la Humanidad sana (dolo), o desinteresándose del riesgo de su contagiosidad (dolo eventual), o por ignorancia, etc. (culposamente), se dedique a la siembra de sus esputos bacilíferos. (Pérez Arguiles, 1959: 25-26)

-Martín (ficcional), marido de Remedios. Él trata de recuperar una vida fuera de la cárcel y personifica a muchos de los familiares que, con su miedo y silencio, abandonaron a algunas presas. Se enfrenta al rechazo de acoger recién nacido o aceptar las mentiras que le cuenta María Topete sobre la muerte durante el parto.

La acción teatral se distribuye entre el despacho de María Topete y la celda de las presas, el espectador entenderá el mundo sin futuro de los vencidos y los nuevos planes ultracatólicos y eugenésicos de la España vencedora. Para cine la adaptación será diferente, y tendrá en cuenta exteriores.

La colmena de personajes muestran ese mosaico de pacatería sexual del que habla Martín Gaite en su Usos amorosos de la posguerra; las complejas y viscerales relaciones que se formaban dentro de las cárceles ente las internas; la búsqueda de un cientificismo que anulara al contrincante "sujeto femenino marxista", según palabras del propio doctor Vallejo-Nágera; la querencia al olvido de algunos maridos hacia sus presas, por miedo o por machismo; y la espera de la muerte como único fin liberador. Mientras, el país vivía en una profunda recesión económica y una brutal represión, con fusilamientos casi diarios durante los primeros años de la inhumana dictadura.

\section{Conclusiones}

Bucear en el proceso del robo de niños es adentrarse en un mundo oscuro donde nada es lo que parece. Con los años, lo que empezó siendo una decisión de carácter político y psiquiátrico, terminó convirtiéndose en un lucrativo negocio para algunos hospitales y parte de la Iglesia. En espera de interpretación de directores escénicos, la construcción de La sonrisa del Caudillo, texto sobre un aspecto histórico/político, huye de imágenes modernas y se resuelve en diálogos y acciones naturalistas en un intento de dar verosimilitud a la historia y para que la mezcla entre personajes reales y de ficción pase inadvertida para el espectador. 


\section{Rubén Buren}

Huir de la pátina de inocencia que, desde la transición de 1975, se le intentó otorgar a los bandos que lucharon dentro de la República, donde el bando perdedor pasó a no tener mácula, sobre todo en lo cercano al PCE de Carrillo, es una labor complicada para un público. Aquí habría que dividir a los espectadores en varios apartados entre los que quieren revanchas ideológicas, los que quieren olvidar y no tienen interés o los que desconocen realmente los contextos históricos. Los testimonios de las presas son un enfoque duro y real de las situaciones vividas por buena parte del país. También hay que tener cuidado de no caer en las trampas que desplegó el franquismo desde la victoria para intentar equiparar las represiones de ambos lados. Las represiones de ambos lados, si bien fueron criminales y sin sentido moral y humano, no fueron iguales ni en número, ni en calidad, ni es sistematización, saliendo vencedor en esos números el bando victorioso por varias decenas de miles.

Es difícil construir personajes desde la posición del escritor que se basa en la realidad. No etiquetar a malos ni a buenos para que cada uno tenga peso emocional y pueda expresar su realidad, al fin y al cabo María Topete y Vallejo-Nágera querían lo mejor para España, "su" España, y por eso llevaron a cabo las acciones que ellos creyeron mejor para la construcción de la nueva sociedad. Caminar en ese medio camino entre la huida de la doctrina y la denuncia es caminar en el filo de una navaja, y es difícil contentar al público, poco receptor, en general en esta década, a consumir obras de este estilo y establecer juicios de valor no emocionales como requiere la catarsis aristotélica propia de los espectáculos. El teatro histórico puede ser un arma para recuperar la memoria colectiva, pero debe hacerlo con rigor e investigación para no convertirse en un panfleto.

La posición dialéctica es clara: las presas y sus hijos son las víctimas, fueron en muchos casos aniquilados, violados, secuestrados, vejados y después silenciados ante el propio aparato de represión estatal y eclesial. Luego, en la transición fueron ocultados y no tuvieron, o fueron mínimos, reconocimientos ni homenajes oficiales. A ellos debemos todo trabajo de investigación, y toda ficción seria, que tienda a recuperar la memoria de un país que parece tener una memoria cada vez más liviana y selectiva. 


\section{Bibliografía citada:}

Anónimo. (1944). Así quiero ser. El niño del Nuevo Estado. Burgos: Hijos de Santiago Rodríguez.

Bandrés, J., \& Llavona, R. "La psicología en los campos de concentración de Franco". Psicothema 1 (1996): 1-11.

Boletín Oficial del Estado, BOE. (20/10/1945).

Bosch Marín, J. (1943). Trabajo, maternidad y lactancia. Madrid: Publicaciones del Instituto Nacional de Previsión.

Cañil, A. R. (2011). Si a los tres años no he vuelto. Barcelona: Espasa Libros.

Claret, P. (1957). Camino Recto y seguro para llegar al cielo. Madrid: Editorial Coculsa.

Conde Suárez, R. Imagina 65.

Esteves, F. La homosexualidad en la España de Franco. La historia de una homofobia institucionalizada.

Franco, F. Modificación. Ley de Vagos y Maleantes. Boletín oficial del Estado. Número 198 . Madrid, España: B.O.E. (17 de Julio de 1954).

Franco, F. (1939). Palabras del Caudillo. 19 Abril 1937-31 Diciembre 1938. Burgos: FET de las JONS.

Gómez Bravo, G. "El desarrollo penitenciario en el primer franquismo (1939-1945)". Hispania Nova. Revista de Historia Contemporánea. Número 6 (2006): 2-20.

González Duro, E. (2008). Los psiquiatras de Franco. Los rojos no estaban locos. Barcelona: Península.

González Rodríguez, A. (1960). Filosofía y política de Spengler. Santiago de Chile: Editorial Andrés Bello.

Guadalajara, A. M. Tomasa Cuevas, una alcarreña contra el olvido.

Hernandez Holgado, F. (2003). Mujeres encarceladas. La prisión de Ventas: de la República al franquismo, 1931-1941. Madrid: Ed. Marcial Pons Ediciones de Historia.

Mamet, D. (2001). Los tres usos del cuchillo. Barcelona: Alba Editorial.

Marañón, G. (1951). Ensayo sobre la vida sexual. Madrid: Espasa-Calpe.

Martín Gaite, C. (2002). Usos amorosos de la posguerra española. Barcelona: Anagrama.

Pérez Arguiles, V. (1959). Discurso sobre la homosexualidad. Zaragoza: Publicaciones de la Real Academia de Medicina del distrito de Zaragoza.

Polo, A. (2006). Gobierno de las poblaciones en el primer franquismo (1939-1945). Cádiz: Universidad de Cádiz. Servicio de puclicaciones.

Sánchez López, R. (2007). Entre la Importancia y la Irrelevancia. Sección femenina: de la República a la Transición. Murcia: Editorial Regional de Murcia.

Southworth, H. (1963). El mito de la cruzada de Franco. París: Ruedo Ibérico. 
Souto, L. C. "La expropiación de la memoria. Ficciones sobre los niños robados durante el franquismo y la dictadura argentina". Revista Internacional de los Estudios Vascos (2011): 218-233.

Truffaut, F. (2008). El cine según Hitchcock. Paracuellos del Jarama (Madrid): Anaya.

Vallejo-Nágera, A. "Biopsiquismo del Fanatismo Marxista". Semana médica española (1938): 172-180.

Vallejo-Nágera, A. (1938b). El Factor Emoción en la España Nueva. Burgos: Rústica Editorial.

Vallejo-Nágera, A. (1938c). Eugamia. Selección de novios. San Sebastián: Editorial Española S.A.

Vallejo-Nágera, A. "Medicina social e higiene mental". Ser Julio (1943): 60.

Vallejo-Nágera, A., \& Martínez, E. "Psiquismo del fanatismo Marxista. Investigaciones Psicológicas en Marxistas femeninos delincuentes". Revista Española de Medicina y Cirugía de Guerra. Número 9 (1939): 398-413.

Vinyes, R. (2010). Irredentas. Las presas políticas y sus hijos en las cárceles franquistas. Madrid: Temas de Hoy.

\section{Filmografía:}

Antena-3. Documental: vida y obra de la monja ladrona de bebés Sor María.

TVE-1. La oscura historia de los niños robados. 